Provided for non-commercial research and education use. Not for reproduction, distribution or commercial use.

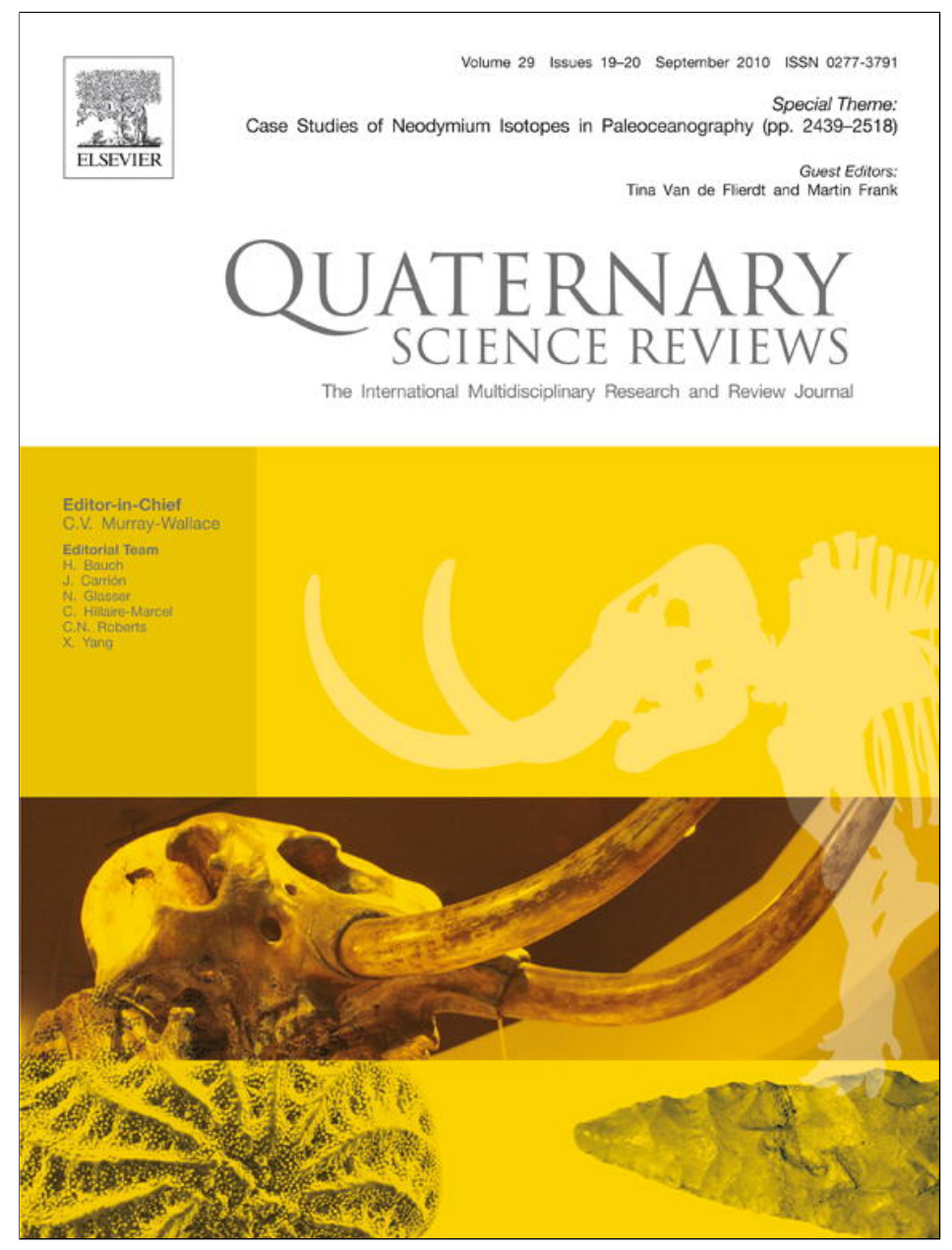

This article appeared in a journal published by Elsevier. The attached copy is furnished to the author for internal non-commercial research and education use, including for instruction at the authors institution and sharing with colleagues.

Other uses, including reproduction and distribution, or selling or licensing copies, or posting to personal, institutional or third party websites are prohibited.

In most cases authors are permitted to post their version of the article (e.g. in Word or Tex form) to their personal website or institutional repository. Authors requiring further information regarding Elsevier's archiving and manuscript policies are encouraged to visit:

http://www.elsevier.com/copyright 


\title{
The sedimentary legacy of a palaeo-ice stream on the shelf of the southern Bellingshausen Sea: Clues to West Antarctic glacial history during the Late Quaternary
}

\author{
C.-D. Hillenbrand ${ }^{\mathrm{a}, *}$, R.D. Larter ${ }^{\mathrm{a}}$, J.A. Dowdeswell ${ }^{\mathrm{b}}$, W. Ehrmann ${ }^{\mathrm{c}}$, \\ A.G.C. Graham ${ }^{a}$, H. Grobe ${ }^{\mathrm{f}}$ \\ ${ }^{a}$ British Antarctic Survey, Madingley Road, Cambridge CB3 OET, United Kingdom \\ ${ }^{\mathrm{b}}$ Scott Polar Research Institute, University of Cambridge, Lensfield Road, Cambridge CB2 1ER, United Kingdom \\ ${ }^{\mathrm{C}}$ Institute for Geophysics and Geology, University of Leipzig, Talstrasse 35, D-04103 Leipzig, Germany \\ ${ }^{\mathrm{d}}$ Department of Geography, Durham University, South Road, Durham DH1 3LE, United Kingdom \\ e School of Environmental Sciences, University of Ulster, Cromore Road, Coleraine BT52 1SA, United Kingdom \\ ${ }^{\mathrm{f}}$ Alfred Wegener Institute for Polar and Marine Research, Am Alten Hafen 26, D-27568 Bremerhaven, Germany
}

\section{A R T I C L E I N F O}

\section{Article history:}

Received 20 January 2010

Received in revised form

7 June 2010

Accepted 15 June 2010

\begin{abstract}
A B S T R A C T
A major trough ("Belgica Trough") eroded by a palaeo-ice stream crosses the continental shelf of the southern Bellingshausen Sea (West Antarctica) and is associated with a trough mouth fan ("Belgica TMF") on the adjacent continental slope. Previous marine geophysical and geological studies investigated the bathymetry and geomorphology of Belgica Trough and Belgica TMF, erosional and depositional processes associated with bedform formation, and the temporal and spatial changes in clay mineral provenance of subglacial and glaciomarine sediments.

Here, we present multi-proxy data from sediment cores recovered from the shelf and uppermost slope in the southern Bellingshausen Sea and reconstruct the ice-sheet history since the last glacial maximum (LGM) in this poorly studied area of West Antarctica. We combined new data (physical properties, sedimentary structures, geochemical and grain-size data) with published data (shear strength, clay mineral assemblages) to refine a previous facies classification for the sediments. The multi-proxy approach allowed us to distinguish four main facies types and to assign them to the following depositional settings: 1) subglacial, 2) proximal grounding-line, 3) distal sub-ice shelf/sub-sea ice, and 4) seasonal open-marine. In the seasonal open-marine facies we found evidence for episodic currentinduced winnowing of near-seabed sediments on the middle to outer shelf and at the uppermost slope during the late Holocene.

In addition, we obtained data on excess ${ }^{210} \mathrm{~Pb}$ activity at three core sites and $44 \mathrm{AMS}{ }^{14} \mathrm{C}$ dates from the acid-insoluble fraction of organic matter (AIO) and calcareous (micro-) fossils, respectively, at 12 sites. These chronological data enabled us to reconstruct, for the first time, the timing of the last advance and retreat of the West Antarctic Ice Sheet (WAIS) and the Antarctic Peninsula Ice Sheet (APIS) in the southern Bellingshausen Sea. We used the down-core variability in sediment provenance inferred from clay mineral changes to identify the most reliable AIO ${ }^{14} \mathrm{C}$ ages for ice-sheet retreat. The palaeo-ice stream advanced through Belgica Trough after $\sim 36.0$ corrected ${ }^{14} \mathrm{C}$ ka before present (B.P.). It retreated from the outer shelf at $\sim 25.5$ ka B.P., the middle shelf at $\sim 19.8$ ka B.P., the inner shelf in Eltanin Bay at $\sim 12.3 \mathrm{ka}$ B.P., and the inner shelf in Ronne Entrance at $\sim 6.3 \mathrm{ka}$ B.P. The retreat of the WAIS and APIS occurred slowly and stepwise, and may still be in progress. This dynamical ice-sheet behaviour has to be taken into account for the interpretation of recent and the prediction of future mass-balance changes in the study area. The glacial history of the southern Bellingshausen Sea is unique when compared to other regions in West Antarctica, but some open questions regarding its chronology need to be addressed by future work.
\end{abstract}

๑) 2010 Elsevier Ltd. All rights reserved.

\footnotetext{
* Corresponding author. Tel.: +44 1223 221340; fax: +44 1223221646.

E-mail address: hilc@bas.ac.uk (C.-D. Hillenbrand).
} 


\section{Introduction}

\subsection{Motivation}

The southern Bellingshausen Sea (Fig. 1) is a major outlet for ice draining both the West Antarctic Ice Sheet (WAIS) and the Antarctic Peninsula Ice Sheet (APIS). Compared to the Antarctic Peninsula margin and the West Antarctic continental margin in the Weddell, Amundsen and Ross seas, however, the southern Bellingshausen Sea and its hinterland are poorly studied areas. Until recently, no huge ice-drainage system had been observed there (e.g. Drewry, 1983), but a ground-based radar survey in 2009/2010 has revealed that directly to the south of Eltanin Bay (Fig. 1) an ice stream extends $\sim 120 \mathrm{~km}$ landward into the WAIS, thereby draining a catchment of $\sim 12,000 \mathrm{~km}^{2}$ through a $\sim 12 \mathrm{~km}$ wide and $\leq 3 \mathrm{~km}$ deep subglacial trough (Bingham et al., 2010).

Both the WAIS and the APIS have shown dramatic signs of ice loss over the last few decades (e.g. Rignot et al., 2004, 2008; Scambos et al., 2004; Thomas et al., 2004; Vaughan, 2008; Pritchard et al., 2009; Wingham et al., 2009). The WAIS is largely grounded below sea level and therefore considered to be the most vulnerable part of the Antarctic Ice Sheet (e.g. Oppenheimer, 1998; Vaughan, 2008). A complete WAIS collapse would raise global sea level by 3.3-5 m (e.g. Vaughan, 2008; Bamber et al., 2009). If recent WAIS drawdown observed in the Amundsen Sea sector continues, this melting alone will cause global sea level to rise by $\sim 1.5 \mathrm{~m}$ (Vaughan, 2008). A collapse of the land-based APIS would raise global sea level by $\sim 0.24 \mathrm{~m}$ (Pritchard and Vaughan, 2007), but the significance of its contribution to sea-level rise in the near future is under debate (cf. Pritchard and Vaughan, 2007; Shepherd and Wingham, 2007; Rignot et al., 2008).

Currently it is unclear to what extent the modern, negative icemass balance affecting the APIS and the WAIS is connected to the longer term deglaciation processes, which started at the termination of the last ice age and may have continued well into the Holocene (e.g. Bindschadler, 1998; Conway et al., 1999; Pudsey and Evans, 2001; Stone et al., 2003; Alley et al., 2005; Domack et al. 2005; Heroy and Anderson, 2005, 2007; Bentley et al., 2006, 2009; Dowdeswell et al., 2008b; Johnson et al., 2008). Similarly, it is unclear if Antarctic deglaciation since the last glacial period has contributed to prominent global meltwater pulses (Clark et al., 2002; Licht, 2004; Peltier, 2005; Bassett et al., 2007). Therefore, knowledge of the history of the WAIS and the APIS since the last ice age is crucial not only for a better understanding of fundamental ice-sheet dynamics, but also for a reliable prediction of future WAIS and APIS behaviour in response to modern global warming (Alley et al., 2005; Vaughan, 2008).

In this paper, we present multi-proxy datasets from marine sediment cores from the West Antarctic continental shelf in the southern Bellingshausen Sea. The subglacial and glaciomarine sequences span the time from the last glacial maximum (LGM) to present (note: the LGM in Antarctica is generally assumed to have occurred between 19.5 and 16.0 ka B.P., e.g. Gersonde et al., 2005, but here we use the term "LGM" in a regional sense, defining the LGM as the time of the last maximum ice-sheet advance in the study area). The new data from seabed surface sediments and sediment cores comprise physical properties, grain-size distribution, contents of organic carbon $\left(\mathrm{C}_{\text {org }}\right)$ and calcite $\left(\mathrm{CaCO}_{3}\right), \mathrm{C}_{\text {org }} /$

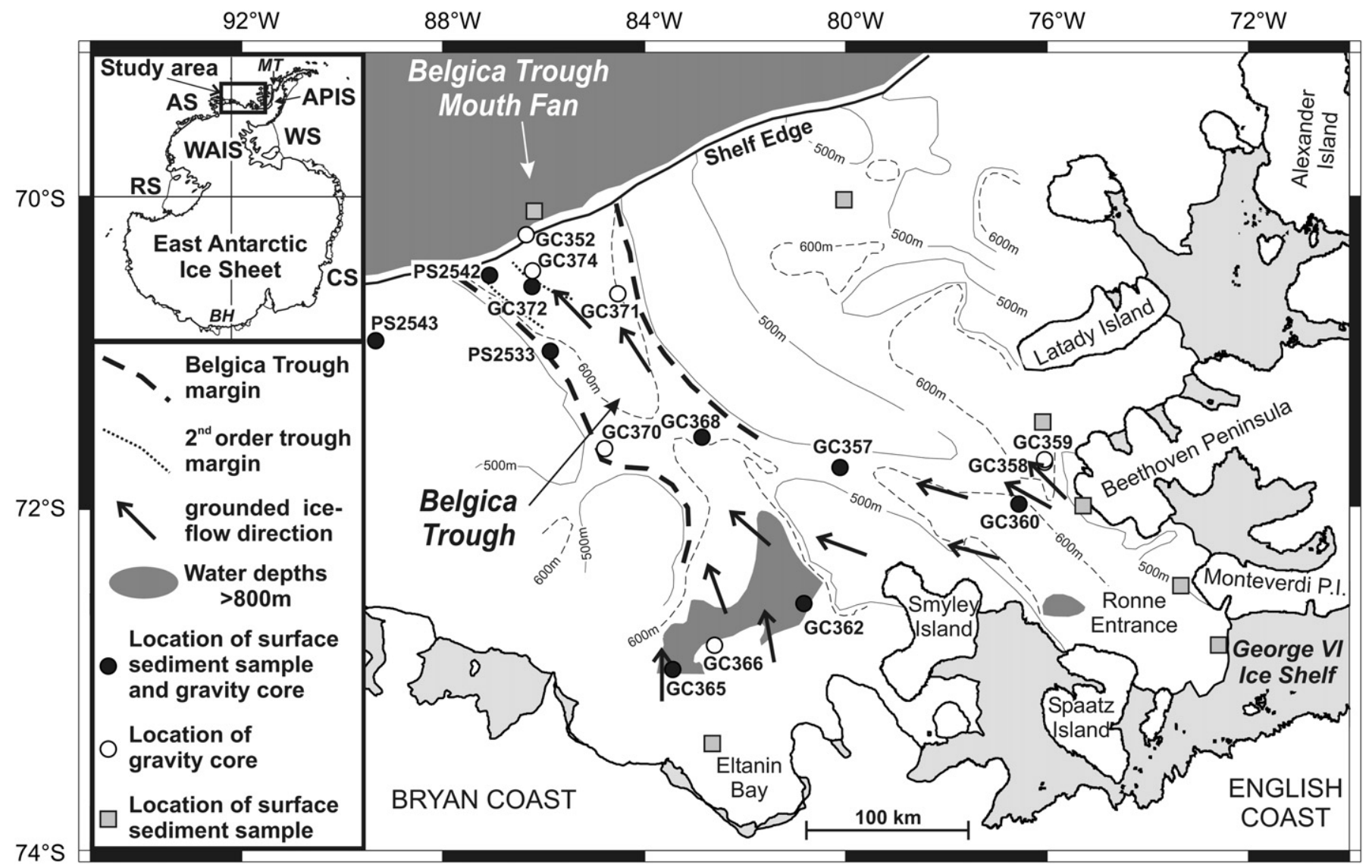

Fig. 1. Map of the southern Bellingshausen Sea with locations of sediment cores and surface sediment samples (note: only identifications of gravity core sites are given, for a summary of all locations see Supplementary Table 1). Grounded ice-flow directions are taken from Ó Cofaigh et al. (2005b). (Inset map: APIS: Antarctic Peninsula Ice Sheet, AS: Amundsen Sea, BH: Bunger Hills, CS: Cosmonaut Sea, MT: Marguerite Trough, RS: Ross Sea, WS: Weddell Sea, WAIS: West Antarctic Ice Sheet). 
nitrogen ratios and isotope geochemical composition of organic matter $\left({ }^{14} \mathrm{C}, \delta \delta^{13} \mathrm{C}_{\mathrm{org}}\right)$, planktonic foraminifera tests $\left(\delta^{18} \mathrm{O}, \delta{ }^{13} \mathrm{C},{ }^{14} \mathrm{C}\right)$ and bulk sediments $\left({ }^{210} \mathrm{~Pb}\right)$. We combine the new data with previously published core data (clay mineral assemblages, shear strength) to refine the lithological classification of the sediments and the reconstruction of their depositional environments. On the basis of our distinction between subglacial, grounding-line proximal, sub-ice shelf/sub-sea ice and seasonal open-marine facies, we establish a radiocarbon chronology that, for the first time, provides a timeline of WAIS and APIS retreat from the southern Bellingshausen Sea shelf since the LGM.

\subsection{Study area}

The southern Bellingshausen Sea is located on the Pacific continental margin of Antarctica (Fig. 1). Water depths on the middle and outer shelf are mostly between $\sim 450 \mathrm{~m}$ and $\sim 650 \mathrm{~m}$, with water depth in deep basins on the inner shelf ranging from $\sim 800 \mathrm{~m}$ to $\sim 1200 \mathrm{~m}$ (Fig. 1; Miller and Grobe, 1996; Ó Cofaigh et al., 2005b; Wellner et al., 2006; Jenkins and Jacobs, 2008). Glaciers and ice streams drain ice from the WAIS via narrow ice tongues into Eltanin Bay and via small ice shelves into bays and inlets along the English Coast and the western Bryan Coast. In contrast, ice drainage from the APIS is mainly via the George VI Ice Shelf that flows into Ronne Entrance. Additionally, small ice shelves along the western coast of Alexander Island drain a local ice cap resting on this island, which we consider to be a part of the APIS.

Surface water currents on the shelf of the southern Bellingshausen Sea are driven by the westward flowing "Antarctic Coastal Current" (e. g. Glasby, 1990). Current speeds seem to be faster over the shelf break and continental slope because of the presence of an oceanographic front, the "Southern boundary of the Antarctic Circumpolar Current" (SBACC) (Orsi et al., 1995). Surface and deep waters north of the SBACC flow eastward as part of the clockwise flowing Antarctic Circumpolar Current (ACC), whereas bottom-water flow on the upper continental rise is affected by a westward flowing current (Hillenbrand et al., 2003). The Antarctic Slope Front, which is an almost circumAntarctic oceanographic feature associated with a westward flowing current along the continental slope, was not observed in the study area (Whitworth et al., 1998). At present, upwelling of relatively warm Circumpolar Deep Water (CDW) takes place at the continental margin in the southern Bellingshausen Sea (Jenkins and Jacobs, 2008). CDW locally protrudes far onto the shelf, where it causes intense basal melting of ice shelves (e.g. Jacobs et al., 1996).

\subsection{Previous work}

The first marine geoscientific data published from the southern Bellingshausen Sea were multi-channel seismic profiles crossing the outer shelf, continental slope and rise (Nitsche et al., 1997, 2000; Cunningham et al., 2002; Scheuer et al., 2006). The seismic stratigraphy on the outer shelf and slope shows a general transition from aggradational to progradational and then back to aggradational geometries. The seismic profiles revealed unconformities on the outer shelf and evidence for debris flows and slumps on the slope. These depositional patterns were interpreted as results of repeated WAIS advances and retreats across the shelf during the Pliocene and Quaternary (Nitsche et al., 1997, 2000; Cunningham et al., 2002; Scheuer et al., 2006). Nitsche et al. $(1997,2000)$ noted that the slope in the study area is gentler $\left(1-2^{\circ}\right)$ but that the shelf break prograded further $(\sim 32 \mathrm{~km})$ than in other areas of the Bellingshausen and Amundsen seas. Moreover, Nitsche et al. (2000) concluded that bathymetric data point to a broad sediment lobe on the slope, centred at $\sim 87.5^{\circ} \mathrm{W}$ (cf. Dowdeswell et al., 2006).
Multi-beam swath bathymetry data published by Wellner et al. $(2001,2006)$ revealed that the seafloor on the shelf north of Eltanin Bay exhibits a wide range of subglacial bedforms including largescale P-forms eroded into bedrock on the inner shelf evolving into elongated drumlins and mega-scale glacial lineations (MSGL) on the middle shelf. Wellner et al. (2001) argued that the bathymetric data point to the presence of a large cross-shelf trough and that sediment cores collected from the MSGLs recovered soft tills. Wellner et al. $(2001,2006)$ inferred from these observations that the WAIS had expanded onto the southern Bellingshausen Sea shelf at the LGM.

In a more comprehensive study, Ó Cofaigh et al. (2005b) presented multi-beam swath bathymetry and sub-bottom profiler data from the shelf and slope. The data revealed the existence of a $\sim 250 \mathrm{~km}$ long, $\leq 150 \mathrm{~km}$ wide and 500-1200 m deep cross-shelf trough ("Belgica Trough"; Fig. 1). On the outer shelf, Belgica Trough is $600-680 \mathrm{~m}$ deep with adjacent shallower banks, where water depths decrease to $400-500 \mathrm{~m}$. A small second-order trough is eroded into the main trough on the outer shelf. The floor of Belgica Trough from the middle to the outer shelf is characterised by MSGLs, which are overprinted by iceberg furrows on the outermost shelf. The MSGLs are formed in an acoustically transparent substratum consisting of a massive diamicton with low shear strength that is interpreted as soft subglacial till (Ó Cofaigh et al., 2005b, 2007). Ó Cofaigh et al. (2005b) concluded that a grounded ice stream flowed through Belgica Trough to the outer shelf (and probably to the shelf break) at the LGM. This ice stream was fed by ice draining both the WAIS through Eltanin Bay and the APIS through Ronne Entrance, with the area of the drainage basin probably exceeding $200,000 \mathrm{~km}^{2}$. Apart from the MSGLs and iceberg scours within Belgica Trough, the authors observed streamlined bedrock and drumlins on the inner shelf and grounding-zone wedges on the inner and middle shelf (cf. Ó Cofaigh et al., 2008). Moreover, Ó Cofaigh et al. (2005b) demonstrated that the sediment lobe on the slope adjacent to Belgica Trough is an associated trough mouth fan ("Belgica TMF"; Fig. 1). Gullies, channels and small slide scars with associated debris flows were detected along the shelf break and on the continental slope (Dowdeswell et al., 2008a; Noormets et al., 2009).

The first detailed geological investigation of marine sediments from the study area was carried out by Hillenbrand et al. (2003), who inferred modern depositional processes, transport pathways of terrigenous detritus and modes of biological productivity by analysing seabed surface and near-surface sediments. The main objective of subsequent work on long sediment cores recovered from the continental shelf, slope and rise of the southern Bellingshausen Sea was the reconstruction of subglacial and glaciomarine depositional processes since the LGM. Hillenbrand et al. (2005) investigated three gravity cores recovered from the western Belgica Trough and the western flank of Belgica TMF and focussed on the interpretation of lithologically similar soft diamictons. The authors used a multi-proxy approach to distinguish subglacial soft till from glaciomarine diamicton and glaciogenic debris flows. Recently, Hillenbrand et al. (2009) presented lithological logs, clay mineral data and preliminary facies interpretations for an additional 18 sediment cores from the shelf and slope. This work deciphered the relationship between the provenance of subglacial, ice marginal and seasonal open-marine (i.e. post-glacial) sediments, which revealed a complex pattern of subglacial erosion, reworking and deposition, and discussed the implications for the reconstruction of ice-drainage patterns at the LGM. Both the studies of multi-beam swath bathymetry data and acoustic sub-bottom profiles (Ó Cofaigh et al., 2005b; Dowdeswell et al., 2008a; Noormets et al., 2009) and the analyses of sediment cores (Hillenbrand et al., 2005, 2009) concluded that the WAIS and APIS 
advanced to the shelf break in the southern Bellingshausen Sea at the LGM.

\section{Material and methods}

Undisturbed seafloor surface sediments were recovered with box and multiple corers and longer sedimentary sequences were collected with gravity corers during cruises JR104 with RRS James Clark Ross in 2004 and ANT-XI/3 with RV Polarstern in 1994 (Miller and Grobe, 1996; Fig. 1, Supplementary Table 1). The sediment cores were described visually and from X-radiographs prepared at the British Geological Survey (Edinburgh, UK). Volume-specific magnetic susceptibility (MS) and wet-bulk density (WBD) of whole cores were measured with GEOTEK multi-sensor core loggers at the British Ocean Sediment Core Research Facility (BOSCORF, Southampton, UK) and the Alfred Wegener Institute for Polar and Marine Research (AWI, Bremerhaven, Germany), respectively. Contents of total carbon (TC), organic carbon $\left(\mathrm{C}_{\mathrm{org}}\right)$ and total nitrogen $\left(\mathrm{N}_{\text {tot }}\right)$ were determined on dried, homogenized bulk sediment samples using LECO Carbon Determinators (CS-125, CS-400 and CNS-2000) at AWI. Relative analytical precision was $1 \%$ for the TC measurements and $3 \%$ for the $\mathrm{C}_{\text {org }}$ measurements, respectively. The $\mathrm{CaCO}_{3}$ contents of the samples were calculated from the TC and $\mathrm{C}_{\mathrm{org}}$ contents. In addition, $\mathrm{C}_{\text {org }} / \mathrm{N}_{\text {tot }}$ ratios were calculated.

Grain-size distribution was analysed on bulk sediment samples (all samples collected on cruise JR104) and decalcified sediment samples (all samples collected on cruise ANT-XI/3), respectively. Grain-size distribution of the coarse fraction $(>62.5 \mu \mathrm{m})$ was investigated by dry sieving, and that of the fine fraction $(<62.5 \mu \mathrm{m})$ of cores GC357, GC366, GC368, GC372 and GC374 was analysed by laser granulometry using a MALVERN microplus 5100 mastersizer at the British Antarctic Survey (BAS). In this study, we use the grainsize data to refine the lithological core descriptions presented in Hillenbrand et al. (2009). The mineralogical analysis of the clay fraction $(<2 \mu \mathrm{m})$ and measurement of shear strength were previously described in Hillenbrand et al. (2009).

Stable oxygen $\left(\delta^{18} \mathrm{O}\right)$ and carbon $\left(\delta^{13} \mathrm{C}\right)$ isotopes of planktonic foraminifera tests (Neogloboquadrina pachyderma sinistral) picked from the coarse fraction ( $>62.5 \mu \mathrm{m}$ ) of gravity cores GC352, GC357, GC368, GC370, GC371, GC372 and GC374 were analysed with a Thermo-Finnigan MAT 253 mass spectrometer at the Godwin Laboratory for Palaeoclimate Research (Cambridge University, UK). Those from multiple core PS2543-3 were analysed with a ThermoFinnigan MAT 251 mass spectrometer at AWI.

Down-core excess ${ }^{210} \mathrm{~Pb}$ activity profiles of box cores BC364X, BC369Y and BC373Y were measured at the Scottish Association for Marine Science (SAMS) Dunstaffnage Marine Laboratory (Oban, UK). The excess ${ }^{210} \mathrm{~Pb}$ activity was determined by analysing total ${ }^{210} \mathrm{~Pb}$ and ${ }^{226} \mathrm{Ra}$ on bulk samples using gamma spectroscopy. Approximately $10 \mathrm{~g}$ of freeze-dried sediment at $1 \mathrm{~cm}$-intervals were carefully weighed into a plastic lid, pressed, and sealed for at least 24 days prior to analysis using high purity germanium detectors (Hp Ge).

All samples selected for AMS radiocarbon dating were prepared and analysed $\left({ }^{14} \mathrm{C}, \mathrm{C}_{\mathrm{org}}, \delta^{13} \mathrm{C}_{\mathrm{org}}\right)$ at the AMS Radiocarbon Facility of the Institute for Physics at Erlangen University (Germany). If present, we dated calcareous material, mainly foraminifera tests of $N$. pachyderma sin. ( $\sim 10 \mathrm{mg}$ ) picked from 1 to $2 \mathrm{~cm}$ thick sediment slices, because these ${ }^{14} \mathrm{C}$ dates provide the most reliable radiocarbon ages (e.g. Domack et al., 2005; Heroy and Anderson, 2007; Rosenheim et al., 2008). All other ${ }^{14} \mathrm{C}$ ages were obtained by dating the acid-insoluble organic fraction (AIO) of bulk sediment samples (cf. Licht et al., 1996, 1998; Domack et al., 1999, 2001; Licht and Andrews, 2002; Pudsey et al., 2006). We give the radiocarbon ages as conventional, i.e. uncorrected, and corrected ${ }^{14} \mathrm{C}$ years before present (B.P.; relative to AD 1950). We corrected ${ }^{14} \mathrm{C}$ ages obtained from calcareous material by subtracting the regional marine reservoir effect (MRE). The MRE in the study area was inferred from the uncorrected ${ }^{14} \mathrm{C}$ age of a scaphopod (Dentalium majorinum; pers. comm. K. Linse, BAS), which was sticking in the sediment surface of box core BC364 recovered from site GC365 on the inner shelf in Eltanin Bay (Fig. 1). This regional MRE of $1294 \pm 51$ yrs B.P. is in agreement with the MRE range of 750-1300 ${ }^{14} \mathrm{C}$ years determined in other parts of the Southern Ocean (e.g. Gordon and Harkness, 1992; Harden et al., 1992; Berkman and Forman, 1996; Domack et al., 2005).

We corrected the AIO ages of the seafloor surface sediments by subtracting the MRE and the local contamination offset (LCO) inferred from the ${ }^{14} \mathrm{C}$ ages of the calcareous (micro-)fossils. The LCO is caused by the mixing of fresh, recently formed organic matter (formed mainly by diatoms) with reworked, fossil organic matter (e.g. Licht et al., 1996; Andrews et al., 1999; Pudsey et al., 2006; Ohkouchi and Eglinton, 2008; Rosenheim et al., 2008; Hillenbrand et al., 2010). At core sites, for which ${ }^{14} \mathrm{C}$ dates from calcareous material were unavailable, we assumed that the surface sediments are of modern age. Following common practice, we corrected the down-core AIO ages by subtracting the core-top ages of box cores taken from the same site or nearby locations (e.g. Licht et al., 1996, 1998; Domack et al., 1999; Licht and Andrews, 2002; Mosola and Anderson, 2006; Pudsey et al., 2006).

For supplementary data see http://doi.pangaea.de/10.1594/ PANGAEA.742532.

\section{Results}

\subsection{Lithostratigraphy}

We previously described and interpreted the lithological units of the studied sediment cores (Hillenbrand et al., 2005, 2009). Here, we refine the original lithological classifications (which were mainly based on visual and smear-slide descriptions) by considering the new grain-size data and summarize the main characteristics of the lithological units from core base to core top (Figs. 2, 3).

The lower lithological unit at sites GC352, GC362, GC365, GC366 and GC368 comprises $0.45-2.1 \mathrm{~m}$ thick, terrigenous, olive grey to dark brown, massive gravelly diamictons, which we had originally described as gravelly sandy muds (Hillenbrand et al., 2009), and structureless to slightly stratified muddy diamictons with low to medium shear strength values ( $\leq 12 \mathrm{kPa}$; Fig. 2). Cores GC357, GC359, GC360, GC370, GC371, GC374, PS2533-2, PS2542-2 and PS2543-1 recovered $0.80-1.65 \mathrm{~m}$ thick, grey, terrigenous, mainly massive and occasionally crudely stratified muddy diamictons at their bases, which are distinct by their medium to high shear strength values ( $\leq 35 \mathrm{kPa}$ ) (Fig. 2; Hillenbrand et al., 2005, 2009). Shear planes were identified in the muddy diamictons of cores GC359 (at $110 \mathrm{~cm}$ below seafloor [cmbsf]) and GC374 (at $181 \mathrm{cmbsf}$; see Fig. 3). The lower lithological unit at site GC372 consists of a massive muddy diamicton with medium shear strength values overlain by a structureless to moderately stratified gravelly diamicton with high shear strength values.

At all sites apart from GC365, the lower lithological unit is overlain by a $0.15-1.10 \mathrm{~m}$ thick middle lithological unit that consists of structureless to slightly laminated or crudely stratified, but rarely bioturbated, gravelly sandy muds (Figs. 2, 3). Initially, we had classified these sediments as sandy muds and muddy sands (Hillenbrand et al., 2009), but the grain-size data reveal also a significant concentration of gravel grains in this unit (Fig. 2). The middle lithological unit is mainly terrigenous. Only occasionally does its top part contain microfossils, for example at site GC368. A soft-sediment clast of faintly laminated mud is observed in the middle lithological unit of core GC362 (Fig. 3). 

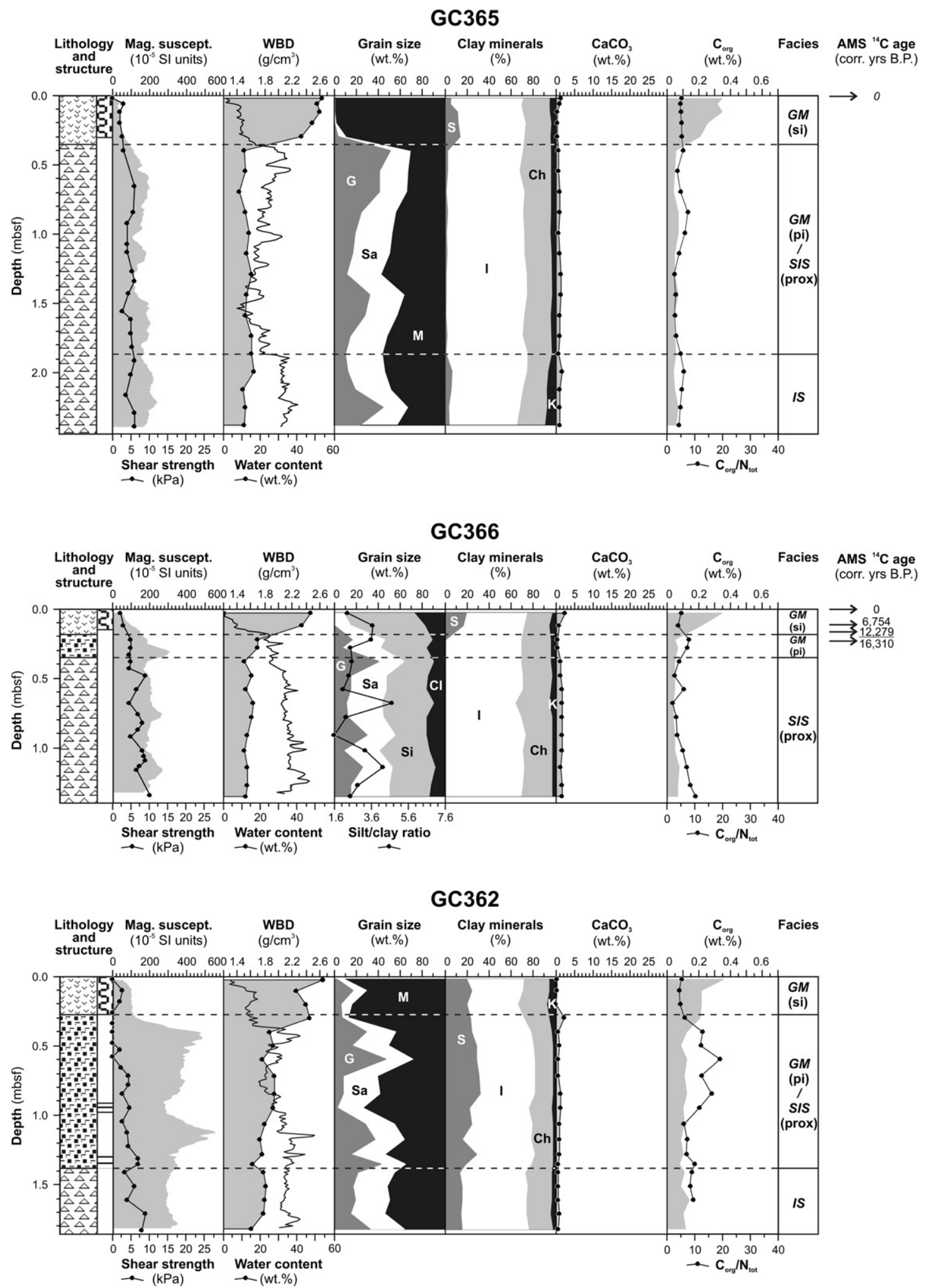

Key:
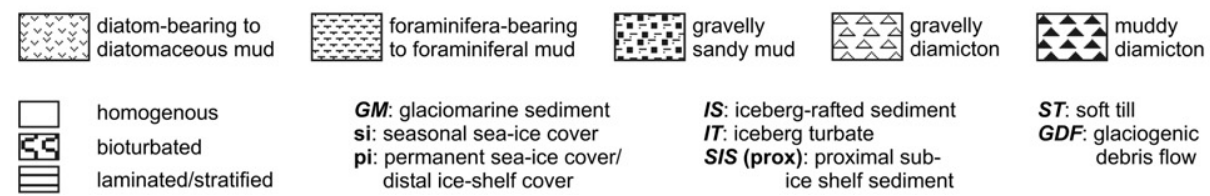

Fig. 2. Lithology, structure, shear strength, magnetic susceptibility, wet-bulk density (WBD), water content, contents of gravel (G) - sand (Sa) - mud (M) and gravel (G) - sand (Sa) - silt ( $\mathrm{Si}$ ) - clay (Cl), respectively, silt/clay ratios, clay mineral assemblages (S: smectite, I: illite, Ch: chlorite, K: kaolinite), contents of $\mathrm{CaCO}_{3}$ and organic carbon $\left(\mathrm{C}_{\text {org }}\right), \mathrm{C}_{\text {org }} / \mathrm{N}_{\text {tot }}$ ratios, interpreted facies types and corrected AMS ${ }^{14} \mathrm{C}$ ages of calcareous (micro-)fossils (numbers in italics) and the AIO (regular numbers) in sediments from the southern Bellingshausen Sea shelf. AMS ${ }^{14} \mathrm{C}$ dates that are considered to be reliable ages for ice-sheet retreat are underlined. 


\section{GC360}

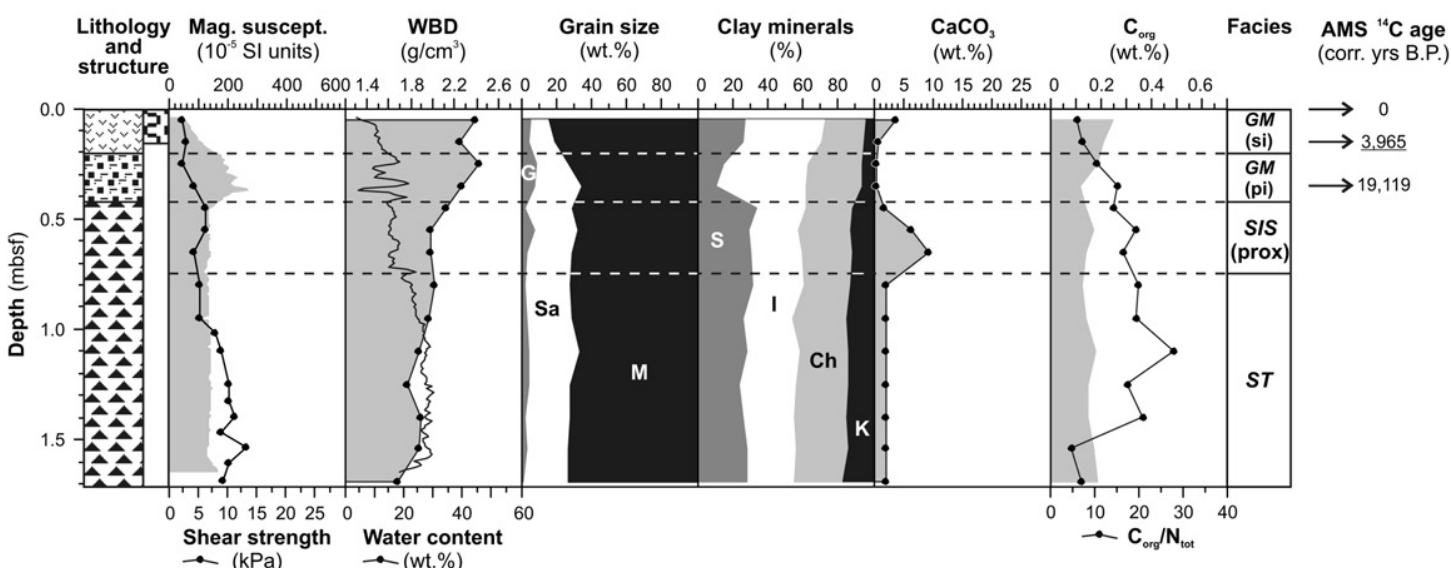

\section{GC358}

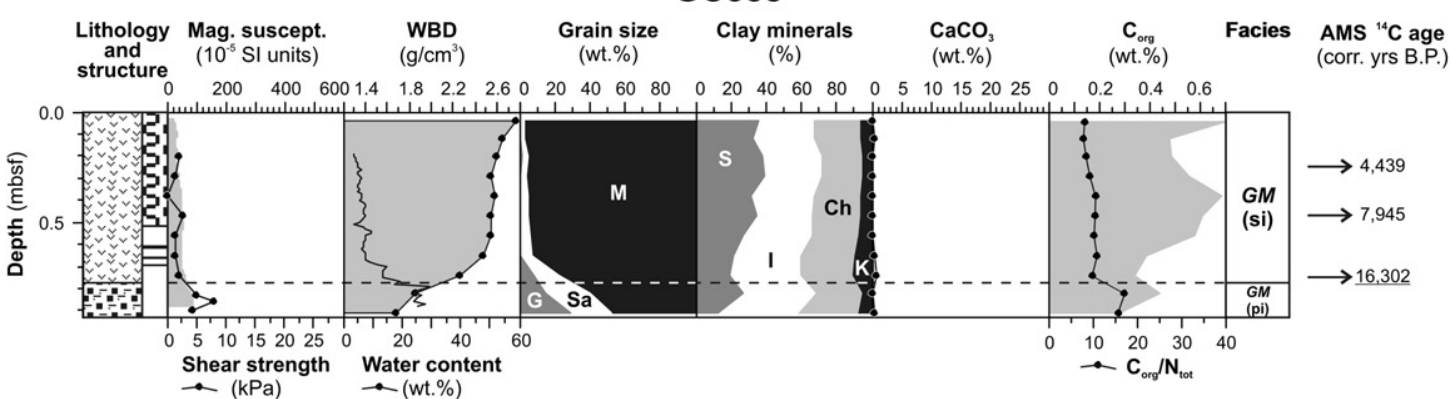

\section{GC359}

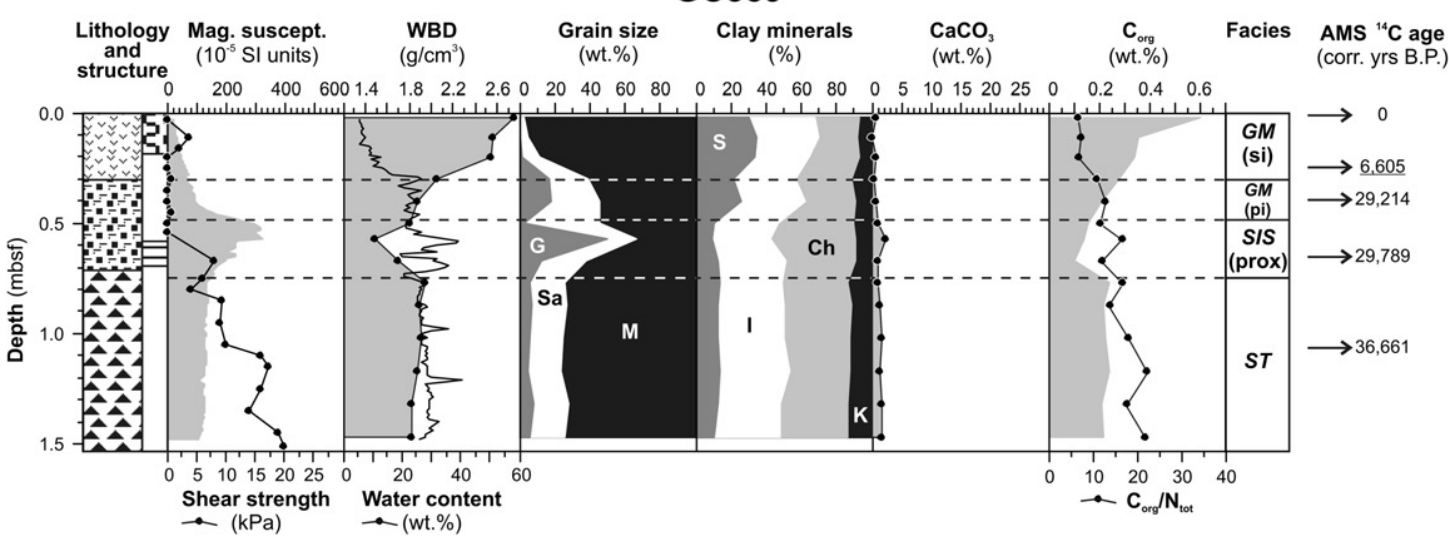

GC357

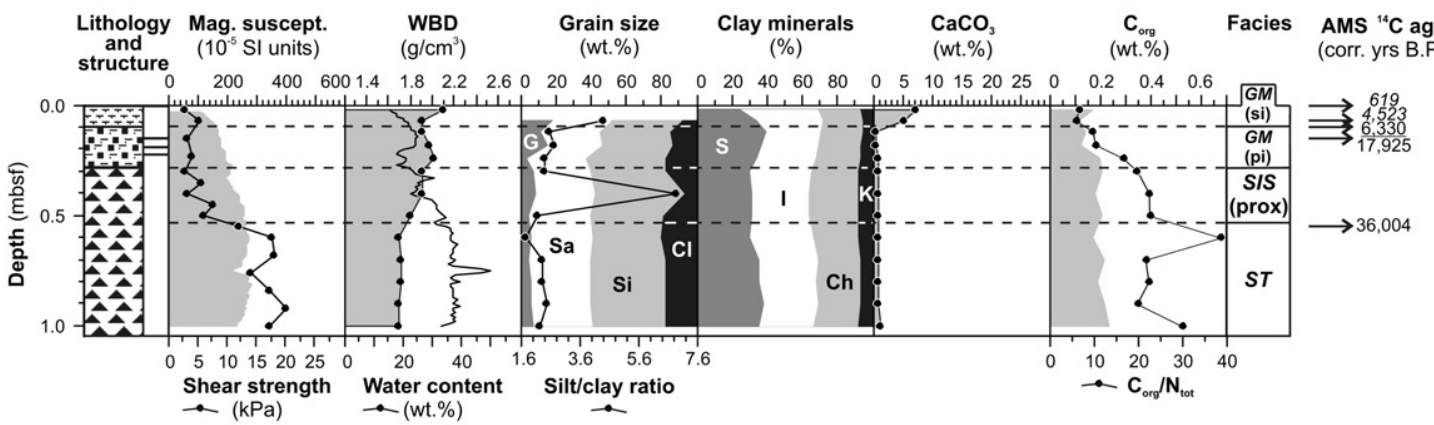

Key:

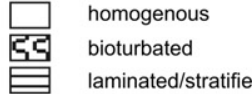
GM: glaciomarine sediment pi: permanent sea-ice cover/ distal ice-shelf cover

IS: iceberg-rafted sediment

SIS (prox): proximal subice shelf sediment muddy

ST: soft till

GDF: glaciogenic debris flow

Fig. 2. (continued). 


\section{GC368}

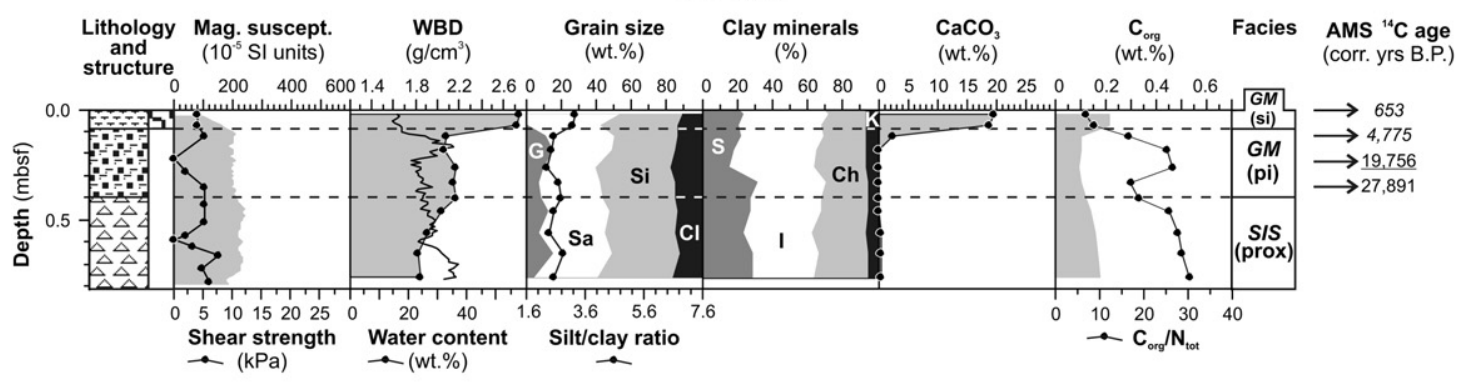

\section{GC370}

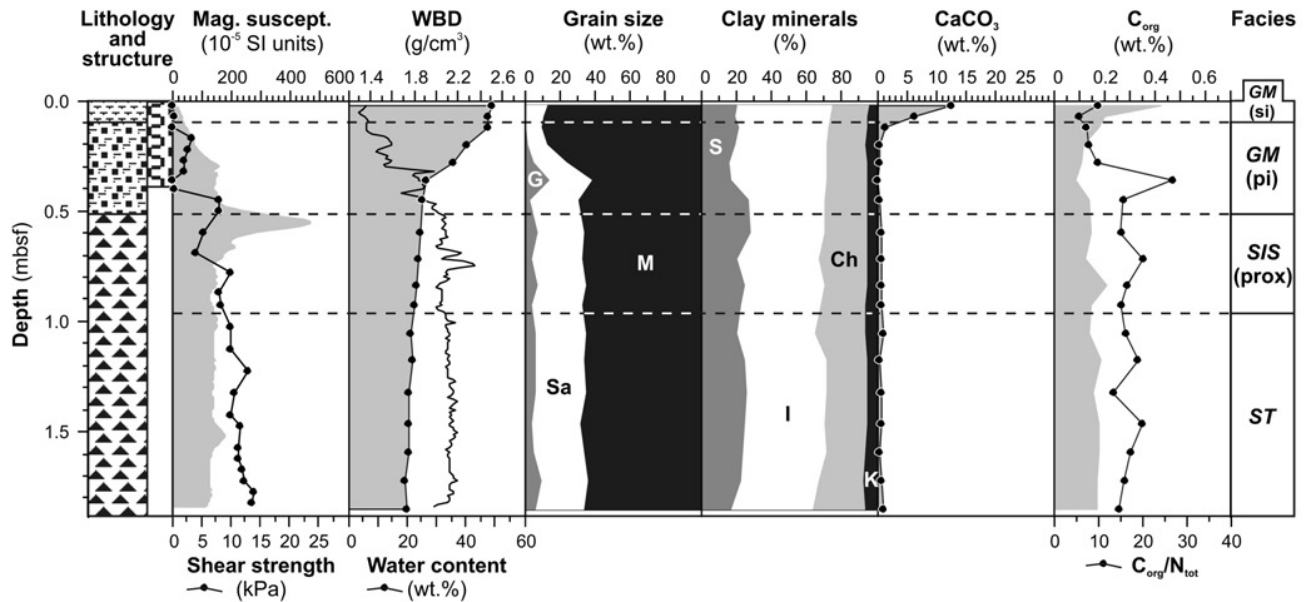

\section{GC371}

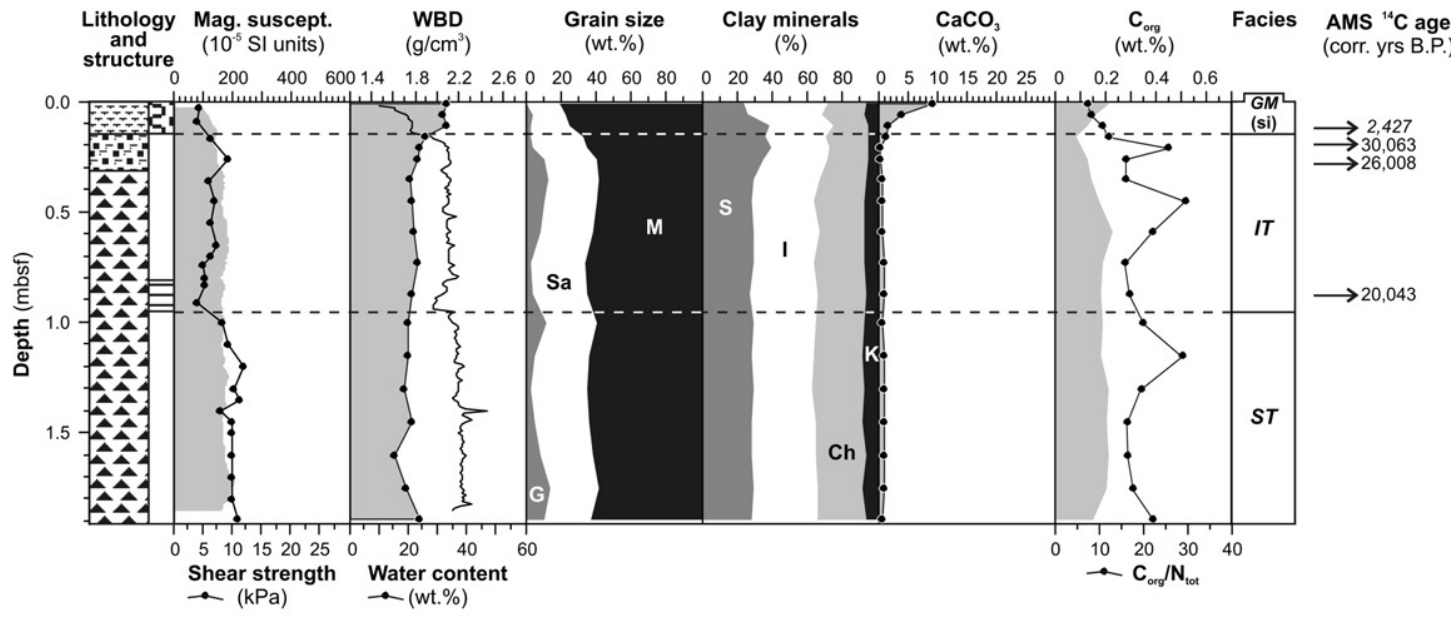

Key:

gravelly
sandy mud

\section{스슬 muddy}

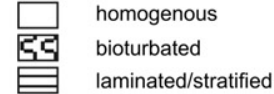
GM: glaciomarine sediment
si: seasonal sea-ice cover

IS: iceberg-rafted sediment

berg turbate

distal ice-shelf cover
dise shelf sediment

ST: soft till

GDF: glaciogenic

debris flow

Fig. 2. (continued) 

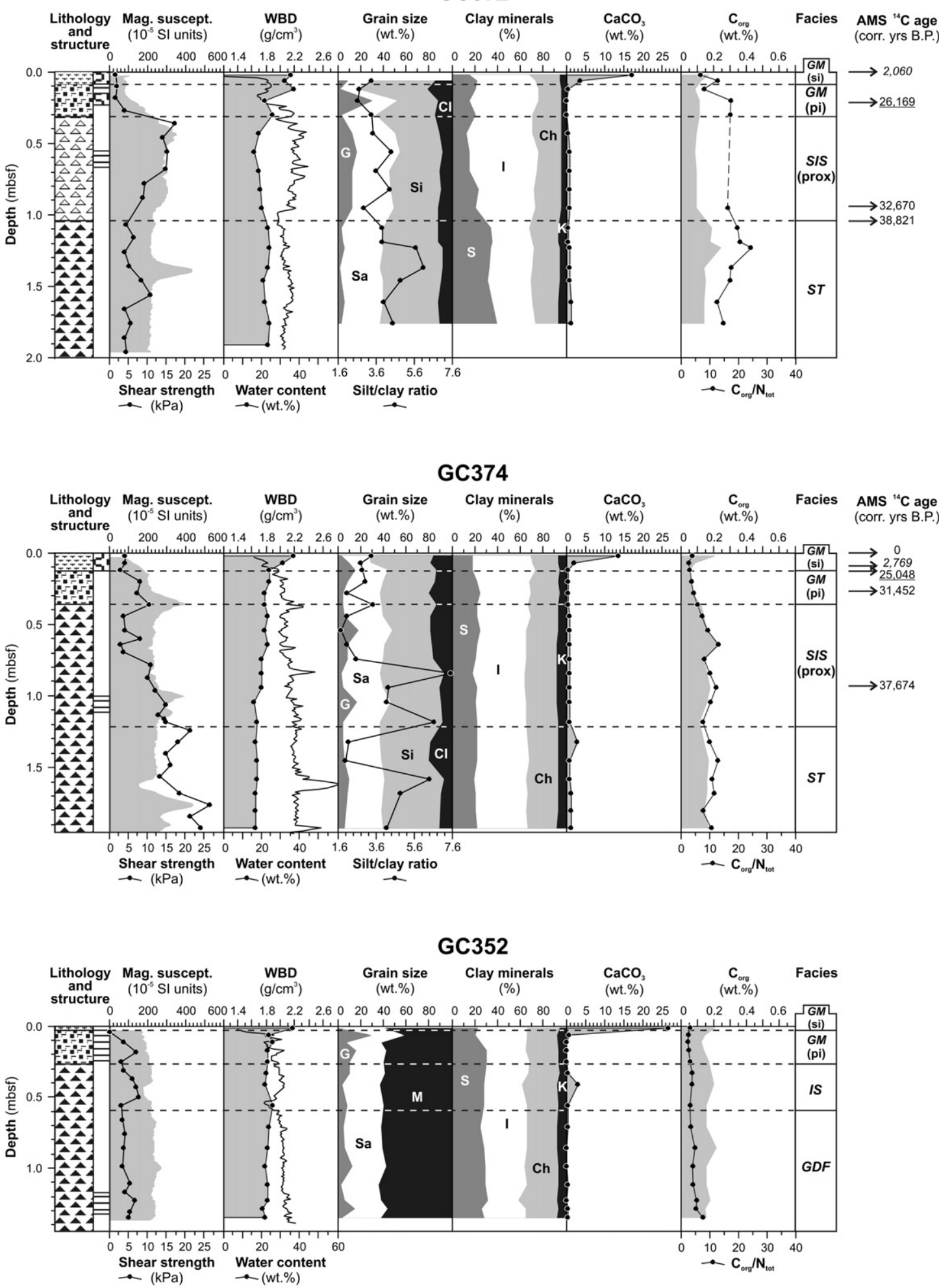

Key:

\begin{tabular}{|ll}
$\square$ & homogenous \\
bioturbated \\
laminated/stratified
\end{tabular}

\section{GC372}

\section{GC374}

\section{GC352}

F

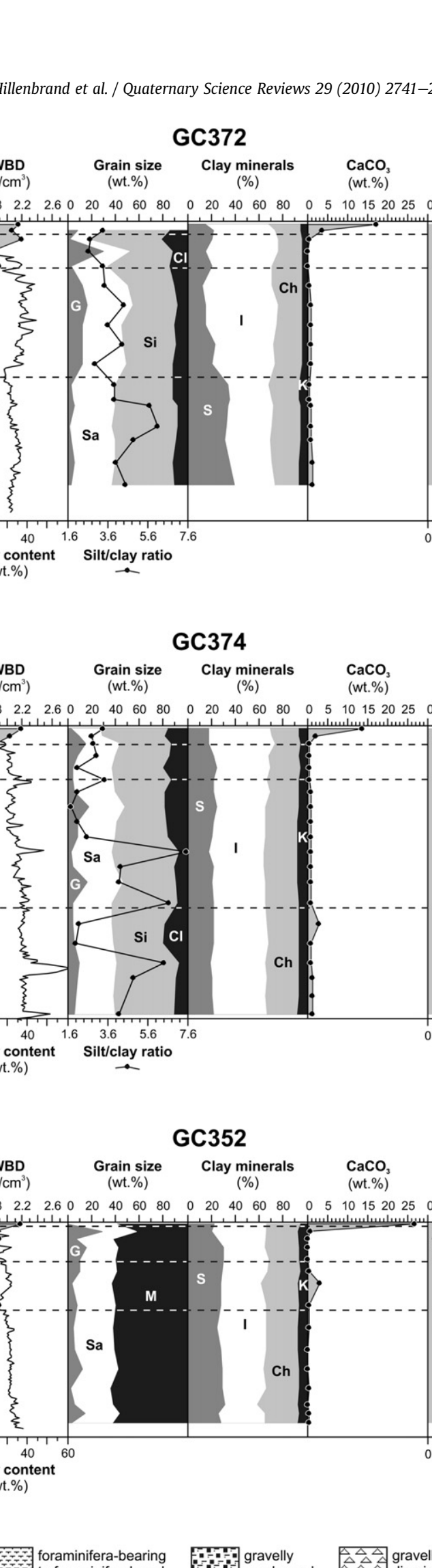

foraminifera-bearing
to foraminiferal mud GM: glaciomarine sediment
si: seasonal sea-ice cover
pi: permanent sea-ice cover/ distal ice-shelf cover
IS: iceberg-rafted sediment ceberg turbate

SIS (prox): proximal subice shelf sediment diamicton

$S T$ : soft till GDF: glaciogenic debris flow

Fig. 2. (continued). 
a

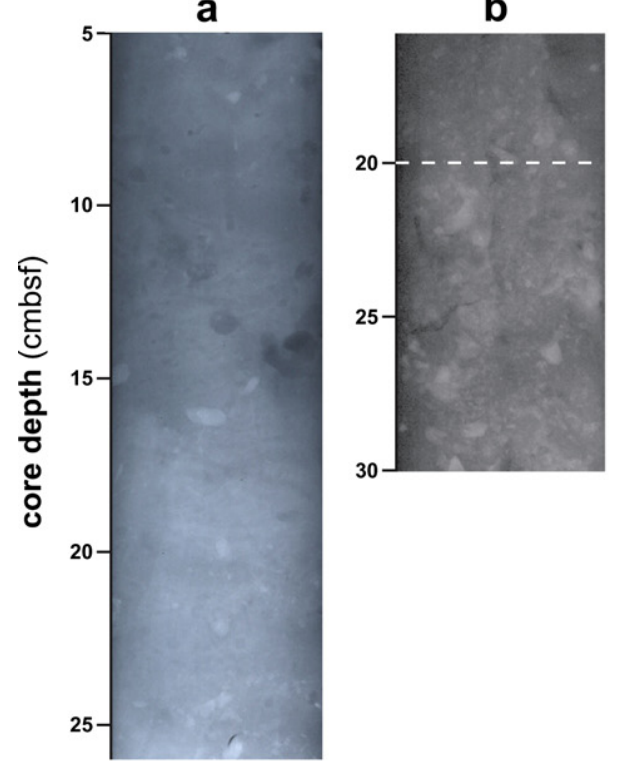

C

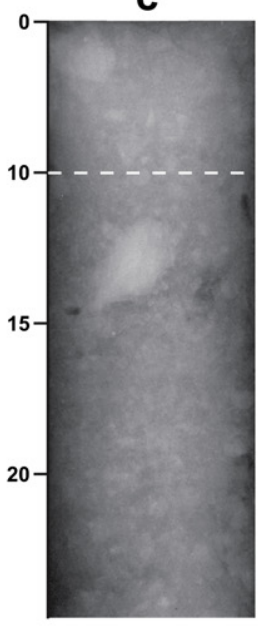

d

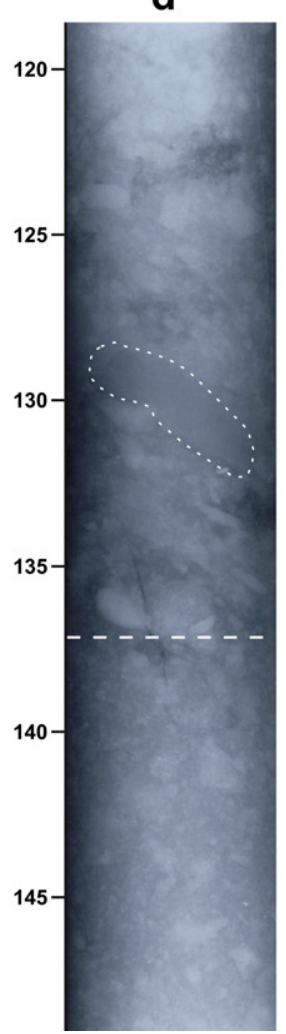

e

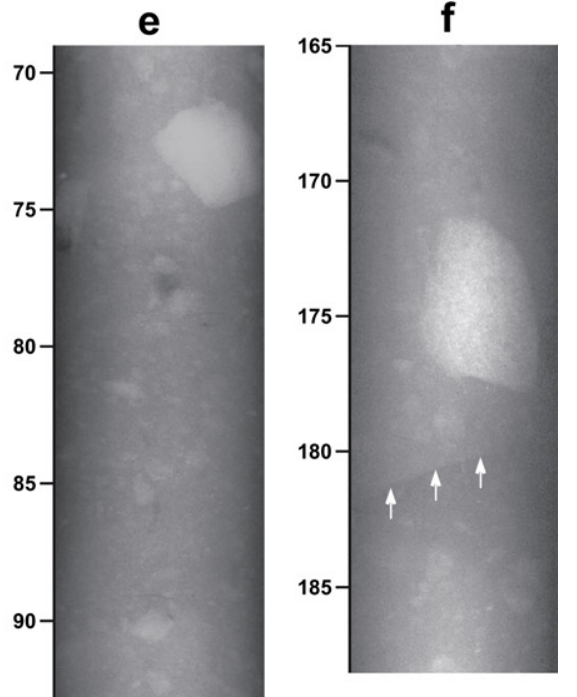

Fig. 3. X-radiographs showing sedimentary structures in the sediment cores from the southern Bellingshausen Sea shelf (lithological boundaries indicated by white dashed lines). a) bioturbated diatom-bearing mud in core GC365; b) structureless diatom-bearing mud underlain by massive gravelly sandy mud in core GC360; c) massive foraminifera-bearing mud underlain by massive to crudely stratified gravelly sandy mud in core GC357; d) massive to crudely stratified gravelly sandy mud with mud clast (white dotted line) underlain by massive gravelly diamicton in core GC362; e) massive muddy diamicton in core GC357; f) massive muddy diamicton with shear plane (white arrows) in core GC374.

The upper lithological unit comprises the near-surface sediments and consists of $\sim 0.20-0.80 \mathrm{~m}$ thick, olive to brownish, diatom-bearing to diatomaceous muds with low concentrations of iceberg-rafted debris (IRD) on the inner shelf (Figs. 2, 3; Supplementary Figure 1a). The upper lithological unit on the middle to outer shelf and at site GC352 from just beyond the shelf edge consists of $\sim 0.02-0.15 \mathrm{~m}$ thick, brown, foraminifera-bearing to foraminiferal muds (Figs. 2, 3; Hillenbrand et al., 2005, 2009) with manganese-coated, gravel- to pebble-sized IRD often scattered on the core surfaces (Supplementary Figure 1b). The upper lithological unit is mainly bioturbated or homogenous. Crude stratification is only observed in core GC358 (Fig. 2).

\subsection{Physical properties}

The lower lithological unit is characterised by relatively constant values of magnetic susceptibility (MS), wet-bulk density (WBD) and water content (Fig. 2). The shear strength and, to a lesser extent, the WBD often decrease up-core in the gravelly and muddy diamictons, while the water content slightly increases. In most cores, shear strength, MS and WBD reach maximum values and water content reaches a minimum within the lower lithological unit. Discrete peaks in the physical properties of the diamictons are associated with larger cobbles and pebbles. In the middle lithological unit water content, MS and WBD show higher variability than in the other units (Fig. 2). At sites GC359, GC360, GC362 and GC366 on the inner shelf the MS reaches maxima within the gravelly sandy muds, and at sites GC359 and GC362 also the WBD shows maximum values. Water content often increases up-core into the biogenic muds of the upper lithological unit, whereas MS, shear strength and
WBD decrease. The diatom- and foraminifera-bearing sediments are characterised by low values of MS, shear strength and WBD that coincide with high water contents (Fig. 2).

\subsection{Grain-size distribution and clay mineral assemblages}

The gravelly diamictons of the lower lithological unit usually contain 10-50 wt.\% gravel, 20-35 wt.\% sand and 30-55 wt.\% clayey silt, while the muddy diamictons contain $<15$ wt.\% gravel, 20-40 wt.\% sand and 55-75 wt.\% clayey silt (Fig. 2). In the middle lithological unit sand contents are 10-45 wt.\% and gravel contents are generally $2-15 \mathrm{wt} . \%$, with gravel maxima ( $\leq 50 \mathrm{wt} . \%$ ) occurring at sites GC359 and GC362 on the inner shelf (Fig. 2). The sediments of the upper lithological unit are dominated by clayey silt with sand contents usually $<40$ wt.\% (Fig. 2). Significant gravel concentrations (5-30 wt.\%) are only observed at sites GC360 and GC362 on the inner shelf and sites GC372 and GC374 on the outer shelf. The sand-silt-clay data reveal that surface sediments on the inner shelf are dominated by silty clay and clayey silt with only low contents of sand (Fig. 4). Sand content generally increases oceanwards, with the highest concentrations occurring on the outer shelf and the upper continental slope. Contents of sand-sized calcareous foraminifera tests are also higher on the outer shelf and beyond the shelf break. However, the seaward increase in sand contents of decalcified samples documents that this increase is at least partly caused by higher concentrations of terrigenous sand particles because the corresponding sediments lack other non-calcareous sand-sized microfossils, such as radiolarians (cf. Hillenbrand et al., 2003). The silt-clay ratios show large variabilities down-core (Fig. 2). At sites GC366, GC372 and GC374 they tend to be lower in 


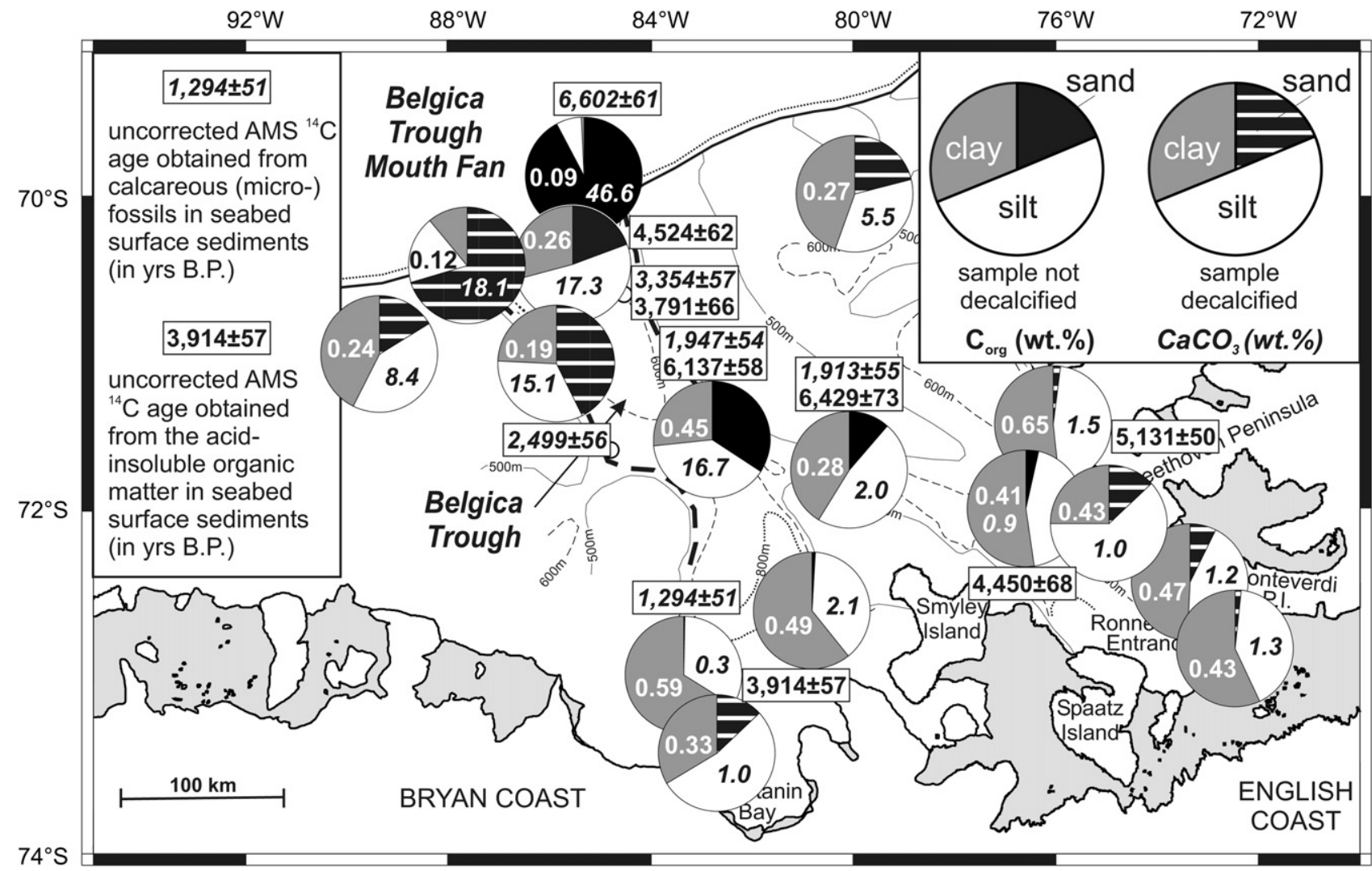

Fig. 4. Lithological composition and radiocarbon dates of seabed surface sediments from the continental shelf and the uppermost continental slope in the southern Bellingshausen Sea. The pie charts give the sand, silt and clay contents (in wt.\%), with decalcified samples indicated by the horizontal pattern of the sand segment. Regular numbers on the pie charts give the $\mathrm{C}_{\text {org }}$ contents and numbers in italics the $\mathrm{CaCO}_{3}$ contents (in wt.\%). Uncorrected $\mathrm{AMS}{ }^{14} \mathrm{C}$ ages are shown by the labelled numbers, with regular numbers giving the ${ }^{14} \mathrm{C}$ ages of the acid-insoluble organic matter (AIO) and numbers in italics giving the ${ }^{14} \mathrm{C}$ ages of calcareous foraminifera tests (N. pachyderma sin.) and a scaphopod (D. majorinum; site BC364/GC365).

the near-surface sediments and reach maximum values in the diamictons of the lower lithological unit.

We previously reported the geographical distribution and the down-core variations of the clay mineral assemblages in the southern Bellingshausen Sea (Hillenbrand et al., 2003, 2005, 2009). The clay minerals comprise mainly smectite, illite and chlorite and only minor contents of kaolinite. Their down-core variations predominantly reflect the major lithological changes (Fig. 2).

\subsection{Contents of inorganic and organic carbon and $C_{\text {org }} / N_{\text {tot }}$ ratios}

Within the lower lithological unit, the $\mathrm{C}_{\text {org }}$ and $\mathrm{CaCO}_{3}$ contents are remarkably constant and range mainly from 0.05 to $0.25 \mathrm{wt} . \%$ and $0.3-2$ wt.\%, respectively (Fig. 2). The muddy diamictons generally contain more $\mathrm{C}_{\text {org }}$ than the gravelly diamictons (e.g. GC372), and the muddy diamicton of core GC360 shows a $\mathrm{CaCO}_{3}$ maximum in its upper part. The $\mathrm{C}_{\text {org }} / \mathrm{N}_{\text {tot }}$ ratios are $<10$ in the muddy diamicton of core GC352 from the uppermost continental slope and in the gravelly diamictons of cores GC362, GC365 and GC366 from the inner shelf west of Smyley Island (Fig. 2). They vary mainly between 10 and 30 in the diamictons at the other core sites (Fig. 2). $\mathrm{C}_{\text {org }} / \mathrm{N}_{\text {tot }}$ ratios of marine organisms typically range from $\sim 4$ to $\sim 10$ and those in terrestrial plants from $\sim 12$ to $\sim 45$ (e.g. Meyers, 1997; Lamb et al., 2006). $\mathrm{C}_{\text {org }} / \mathrm{N}_{\text {tot }}$ ratios up to 30 have been reported from Holocene Antarctic shelf sediments and were attributed to enhanced supply of terrestrial organic material or (lipid-rich) organic matter from marine benthic algae in combination with limited nitrogen availability under sea-ice cover (e.g. Yoon et al., 2000, 2010; McMinn et al., 2001; Presti et al., 2003). Inorganic nitrogen is likely to contribute to the low $\mathrm{C}_{\text {org }} / \mathrm{N}_{\text {tot }}$ ratios in the gravelly diamictons at sites GC362, GC365 and GC366, because these sediments are characterised by the highest illite contents in the study area (Fig. 2). Illite is well known to contain more inorganicfixed nitrogen than other clay minerals (e.g. De Lange, 1992).

The $\mathrm{C}_{\text {org }}$ content in the middle lithological unit is generally 0.05-0.20 wt.\%, but shows minimum values (compared to the other units) at all sites. Apart from sites GC359 and GC362, the $\mathrm{CaCO}_{3}$ content in this unit is $<1 \mathrm{wt} . \%$ and also at its minimum. The $\mathrm{C}_{\mathrm{org}} / \mathrm{N}_{\text {tot }}$ ratios in the middle lithological unit are similar to those of the lower unit, but often decrease towards the top of the unit (Fig. 2). Within the upper lithological unit the $\mathrm{C}_{\text {org }}$ contents increase towards the surface, with the diatom-bearing sediments on the inner shelf exhibiting the highest $\mathrm{C}_{\text {org }}$ contents. A similar pattern is observed in the $\mathrm{CaCO}_{3}$ contents of the foraminifera-bearing sediments from the middle to outer shelf and beyond the shelf edge (Fig. 2; cf. Hillenbrand et al., 2003 , 2005). Here, the $\mathrm{CaCO}_{3}$ contents mainly reflect the concentrations of $N$. pachyderma sin. tests. At most core sites the $\mathrm{C}_{\mathrm{org}} / \mathrm{N}_{\text {tot }}$ ratios are $\leq 10$ in the upper lithological unit and thus exhibit a relative minimum when compared to the $\mathrm{C}_{\text {org }} / \mathrm{N}_{\text {tot }}$ ratios of the other units.

The seafloor surface sediments contain $0.1-0.7 \mathrm{wt} . \% \mathrm{C}_{\text {org }}$, with the highest values (0.3-0.7 wt.\%) observed on the inner shelf (Fig. 4; cf. Hillenbrand et al., 2003). The $\mathrm{CaCO}_{3}$ contents are $0.3-2.1 \mathrm{wt} . \%$ on the inner shelf and range from 15.1 to $18.1 \mathrm{wt} . \%$ on the middle and outer shelf in Belgica Trough, and from 5.5 to $8.4 \mathrm{wt}$. $\%$ on the outer shelf beyond the trough. The highest $\mathrm{CaCO}_{3}$ content of $46.6 \mathrm{wt}$.\% was found on the upper continental slope (Fig. 4). Thus, the geographical pattern of the $\mathrm{CaCO}_{3}$ contents resembles that of the sand contents (cf. Hillenbrand et al., 2003). 


\subsection{Stable isotopic composition of planktonic foraminifera tests}

Only the near-surface sediments from the middle and outer shelf and uppermost slope contained enough calcareous foraminifera to analyse the $\delta^{18} \mathrm{O}$ and $\delta^{13} \mathrm{C}$ composition of their tests. The $\delta^{18} \mathrm{O}$ signal in the gravity cores from the shelf varies less than $0.15 \%$ 。 around an average value of $\sim 3.45 \%$ and shows only a minor downcore increase at sites GC368, GC370 and GC372 (Fig. 5a). In multiple core PS2543-3 the $\delta^{18} \mathrm{O}$ signal is relatively constant, too, but varies around a lower average value of $\sim 3.1 \%$. Taking into account the consistent down-core pattern at all shelf sites, we consider the $\delta^{18} \mathrm{O}$ offset of $\sim 0.35 \%$ in core PS2543-3 to be a methodological artefact (the $\delta^{18} \mathrm{O}$ values for this core were analysed in a different laboratory with a different mass spectrometer, see Section 2). Also core GC352 shows only minor $\delta^{18} \mathrm{O}$ variations around a mean value of $\sim 3.45 \%$, but its lowermost sample exhibits a $\delta^{18} \mathrm{O}$ value of $3.9 \%$, the heaviest $\delta^{18} \mathrm{O}$ value measured at any of the sites (Fig. 5a). The near-surface $\delta^{13} \mathrm{C}$ values range from 1.1 to $1.2 \%$ and decrease down-core by $\sim 0.3-0.5 \%$ to a sub-surface minimum at all sites (Fig. $5 \mathrm{~b}$ ). In cores GC370, GC371, PS2543-3 and GC372 the $\delta^{13} \mathrm{C}$ values show a slight increase below this minimum.

\subsection{Excess ${ }^{210} \mathrm{~Pb}$ activity}

Sub-core BC364X was taken from site GC365 on the inner shelf in Eltanin Bay and shows a reasonably high excess ${ }^{210} \mathrm{~Pb}$ activity of $283 \mathrm{~Bq} / \mathrm{kg}$ at the core top (Fig. 6). Non-local mixing caused by bioturbation is evident at a depth from 6 to $9 \mathrm{cmbsf}$, and also affects the lowermost interval of the excess ${ }^{210} \mathrm{~Pb}$ profile. Sub-core BC369Y was recovered from site GC368 on the middle shelf in Belgica
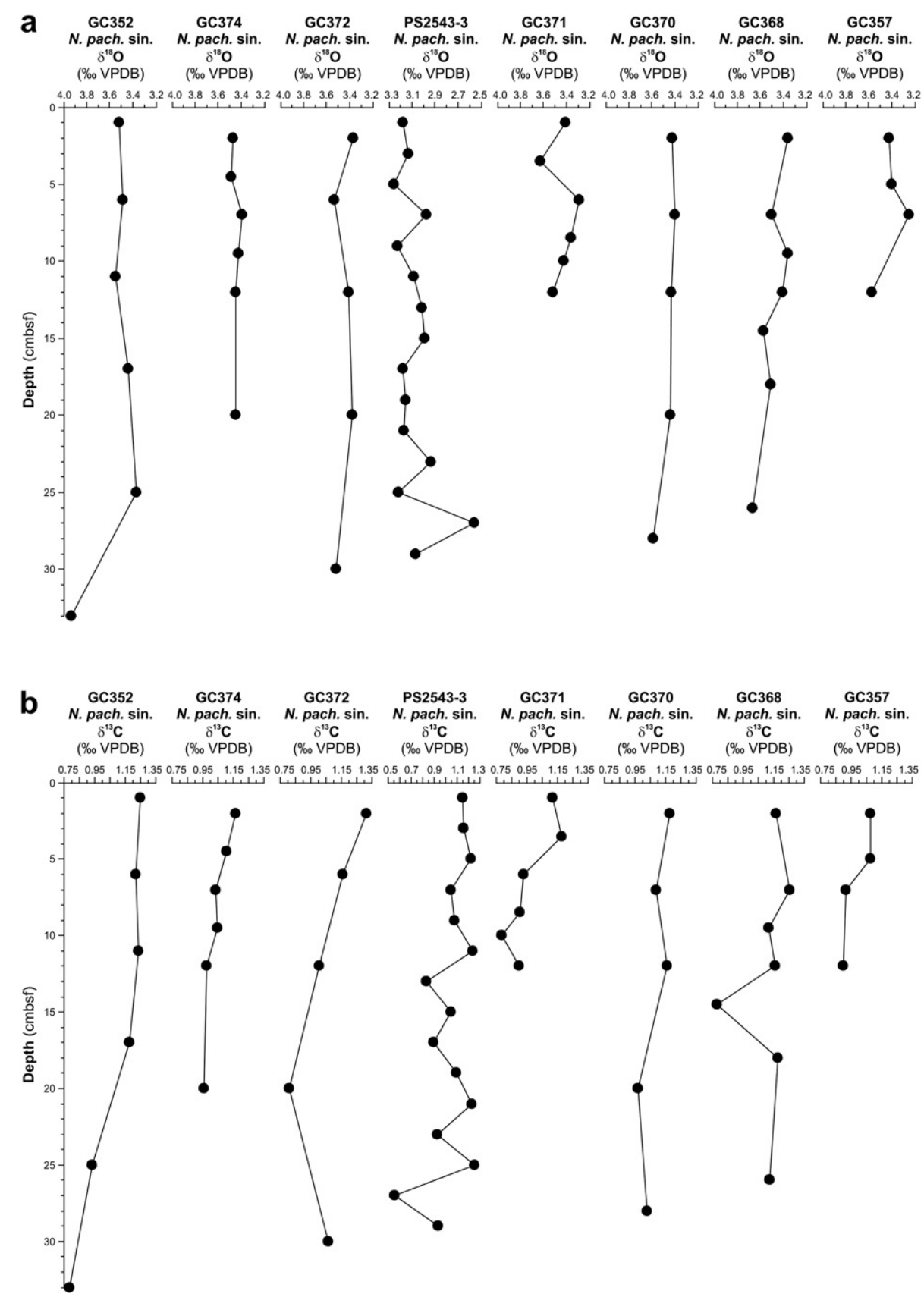

Fig. 5. Oxygen (a) and carbon isotope composition (b) of planktonic foraminifera tests (N. pachyderma sin.) in near-surface sediments from the uppermost slope (GC352), the outer shelf (GC374, GC372, GC371, PS2543-3) and the middle shelf (GC370, GC368, GC357) in the southern Bellingshausen Sea. Note different $\delta^{18} \mathrm{O}$ and $\delta^{13} \mathrm{C}$ scale bars for core PS2543-3. 

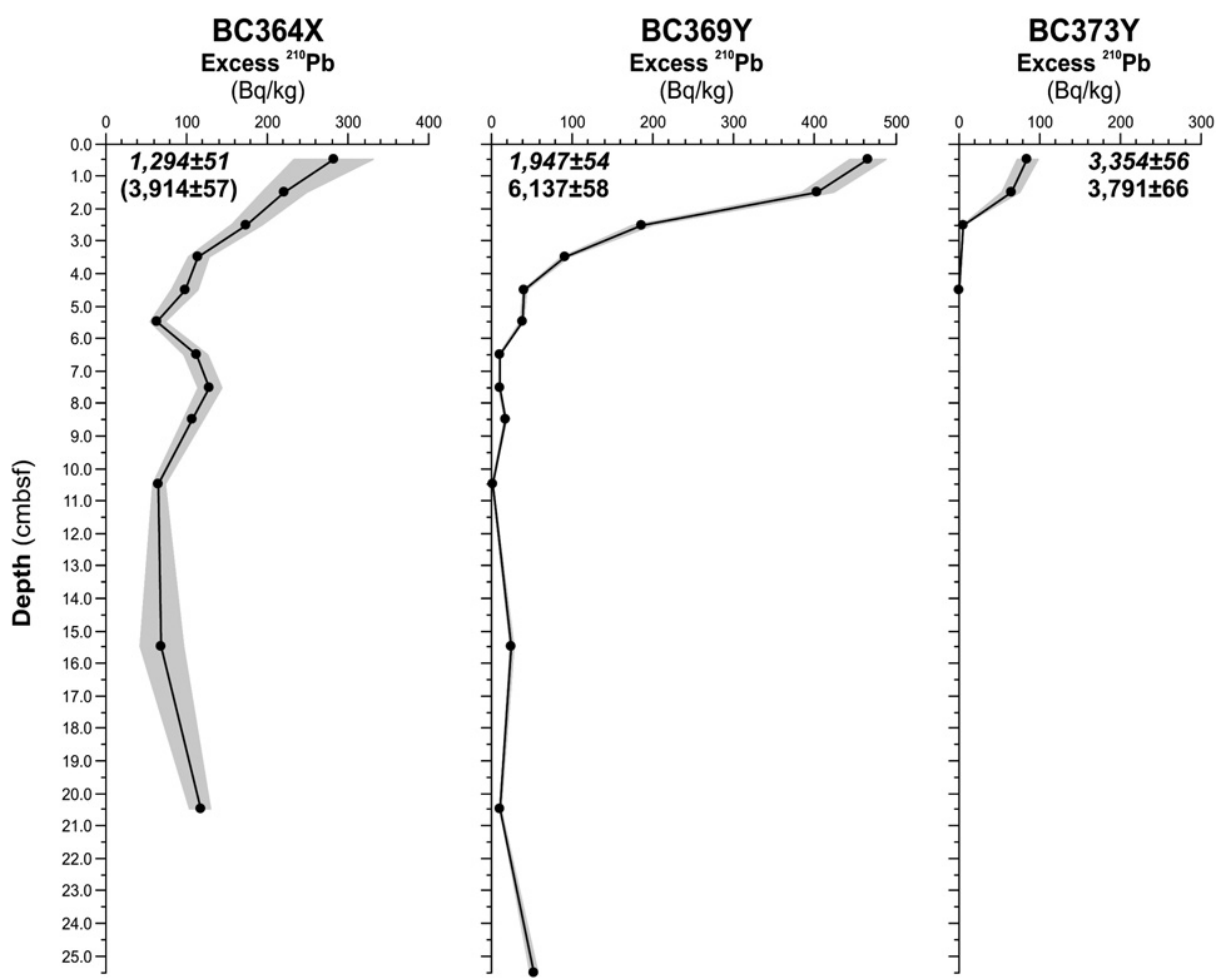

Fig. 6. Down-core excess ${ }^{210} \mathrm{~Pb}$ profiles of near-surface sediments from the inner (BC364X/GC365), middle (BC369Y/GC368) and outer shelf (BC373Y/GC372) in the southern Bellingshausen Sea. The numbers near the core tops give the uncorrected AMS ${ }^{14} \mathrm{C}$ ages (in years B.P.) of calcareous (micro-)fossils (numbers in italics) and of the AIO (regular numbers) of the surface sediments (number in brackets is from site GC366).

Trough and exhibits a classic decay profile with a very high excess ${ }^{210} \mathrm{~Pb}$ activity of $466 \mathrm{~Bq} / \mathrm{kg}$ at the surface (Fig. 6). Sediment mixing by bioturbation is very minor and mainly affects the lower part of the profile. In sub-core BC373Y, which was collected from site GC372 on the outer shelf in Belgica Trough, excess ${ }^{210} \mathrm{~Pb}$ activity is just $85 \mathrm{~Bq} / \mathrm{kg}$ at the surface and could only be detected down to 5 cmbsf depth (Fig. 6). This indicates condensed sedimentation and possibly a lack of modern sediments at the core top.

\subsection{Radiocarbon dates}

\subsubsection{AMS ${ }^{14} \mathrm{C}$ ages of seafloor surface sediments}

In the surface sediments, the uncorrected AMS ${ }^{14} \mathrm{C}$ ages of calcareous (micro-)fossils increase from $\sim 1.3 \mathrm{ka}$ B.P. on the inner shelf to $\sim 1.9 \mathrm{ka}$ B.P. on the middle shelf and $\sim 2.5-3.4 \mathrm{ka}$ B.P. on the outer shelf (Table 1; Figs. 4, 6). The oldest surface ${ }^{14} \mathrm{C}$ age of $6.6 \mathrm{ka}$ B.P. was obtained from foraminifera tests at site BC355 located just beyond the shelf edge. The seaward increase of ${ }^{14} \mathrm{C}$ ages resembles the spatial pattern observed in the sand and $\mathrm{CaCO}_{3}$ contents. The uncorrected AMS ${ }^{14} \mathrm{C}$ ages of the AIO in the surface sediments range from $\sim 3.9$ to $5.1 \mathrm{ka}$ B.P. on the inner shelf, $\sim 6.1-6.4$ ka B.P. on the middle shelf, and $\sim 3.8-4.5 \mathrm{ka}$ B.P. on the outer shelf (Table 1 ; Figs. 4, 6). The AIO ages are consistently older than the ${ }^{14} \mathrm{C}$ ages obtained from the calcareous material, which we attribute to the contamination of the organic carbon with recycled, fossil organic matter.

\subsubsection{AMS ${ }^{14} \mathrm{C}$ down-core ages}

Uncorrected AMS ${ }^{14} \mathrm{C}$ ages obtained from calcareous foraminifera in the upper lithological unit and the top part of the middle lithological unit vary between $3.7 \mathrm{ka}$ B.P. at site GC371 and $6.1 \mathrm{ka} \mathrm{B.}$ $\mathrm{P}$. at site BC369/GC368, with the corresponding corrected ages ranging from $2.4 \mathrm{ka}$ B.P. to $4.8 \mathrm{ka}$ B.P. (Table 1; Figs. 2, 7).
Uncorrected AMS ${ }^{14} \mathrm{C}$ ages of AIO samples from the basal part of the upper lithological unit vary between 8.4 ka B.P. at site GC360 and 21.4 ka B.P. at site GC358, corresponding to corrected ages of 4.0 ka B.P. and 16.3 ka B.P., respectively. The uncorrected AMS ${ }^{14} \mathrm{C}$ ages of AIO samples from the basal part of the middle lithological unit range from $23.6 \mathrm{ka}$ B.P. at site GC360 to $34.9 \mathrm{ka}$ B.P. at site GC359, while the corrected AIO ages vary between $19.1 \mathrm{ka}$ B.P. at site GC360 and 31.5 ka B.P. at site GC374. The uncorrected AIO dates from the lower lithological unit span 22.5 ka B.P. at site GC371 to 41.8 ka B.P. at site GC357, while the corrected AIO ages from this unit vary between $20.0 \mathrm{ka}$ B.P. at site GC371 and $38.8 \mathrm{ka}$ B.P. at site GC372. The only age reversals are observed in the middle and lower lithological units of core GC371. At most core sites, the corrected AMS ${ }^{14} \mathrm{C}$ ages from the top part of the middle lithological unit are significantly younger than those from its basal part (Fig. 2), which is reflected by a corresponding kink in age-depth profiles for the cores (Fig. 7). These profiles illustrate that the ${ }^{14} \mathrm{C}$ age increase from the top part of the middle lithological unit into its basal part is more pronounced than the ${ }^{14} \mathrm{C}$ age increase into the underlying diamictons.

3.7.3. AIO radiocarbon dates and their relation to $C_{\text {org }}$ content and ${ }^{13} C_{\text {org }}$ composition of the organic matter

In addition to their different depositional ages, the ${ }^{14} \mathrm{C}$ dates obtained from the AIO may be affected by significant changes in i) the $\mathrm{C}_{\text {org }}$ content of the sediments and ii) the origin of the dated organic material (cf. Licht et al., 1998; Licht and Andrews, 2002; Ohkouchi and Eglinton, 2006). A low $\mathrm{C}_{\text {org }}$ content may result from a low supply of fresh organic carbon and a dominance of reworked, fossil organic matter, which would offset the $\mathrm{AIO}^{14} \mathrm{C}$ date towards an older age. Enhanced supply of reworked, fossil terrestrial organic substance may be identified by a $\mathrm{C}_{\text {org }} / \mathrm{N}_{\text {tot }}$ ratio $>12$ and a strongly depleted $\delta^{13} C_{\text {org }}$ ratio (e.g. Meyers, 1997; Lamb et al., 2006). 
Table 1

Uncorrected and corrected AMS ${ }^{14} \mathrm{C}$ dates (including errors) from the studied sediment cores. Total organic carbon $\left(\mathrm{C}_{\mathrm{org}}\right)$ content and $\delta^{13} \mathrm{C}_{\mathrm{org}}$ ratios of the dated samples are also given. The samples that are considered to give the most reliable AMS ${ }^{14} \mathrm{C}$ ages for ice-sheet retreat (see Section 4.2.2) are highlighted in italics. S: scaphopod, F: planktonic foraminifera, AIO: acid-insoluble organic matter, MRE: regional marine reservoir effect, LCO: local contamination offset.

\begin{tabular}{|c|c|c|c|c|c|c|c|c|c|}
\hline Core & $\begin{array}{l}\text { Depth } \\
\text { (cmbsf) }\end{array}$ & $\begin{array}{l}\text { Laboratory } \\
\text { code }\end{array}$ & $\begin{array}{l}\text { Sample } \\
\text { material }\end{array}$ & $\begin{array}{l}\text { Uncorr. }{ }^{14} \mathrm{C} \text { age } \\
\text { (yrs B.P.) }\end{array}$ & MRE (yrs) & $\begin{array}{l}\text { LCO } \\
\text { (yrs) }\end{array}$ & $\begin{array}{l}\text { Corr. }{ }^{14} \mathrm{C} \text { age } \\
\text { (yrs B.P.) }\end{array}$ & $\begin{array}{l}\text { Corg }_{\text {or }} \\
\text { (wt.\%) }\end{array}$ & $\begin{array}{l}\delta^{13} C_{\text {org }} \\
(\% \text { PDB })\end{array}$ \\
\hline ВС364 & $0-1$ & Erl-6962 & $\mathrm{S}$ & $1294 \pm 51$ & 1294 & $\mathrm{~N} / \mathrm{A}$ & $0 \pm 51$ & $\mathrm{~N} / \mathrm{A}$ & 1.4 \\
\hline GC366 & $0-1$ & Erl-9294 & $\mathrm{AIO}$ & $3914 \pm 57$ & 1294 & 2620 & $0 \pm 108$ & 0.35 & -24.1 \\
\hline GC366 & $11.5-12.5$ & Erl-9758 & AIO & $10,668 \pm 119$ & 1294 & 2620 & $6754 \pm 227$ & 0.22 & -23.7 \\
\hline GC366 & $16.5-17.5$ & Erl-9759 & $A I O$ & $16,193 \pm 196$ & 1294 & 2620 & $12,279 \pm 304$ & 0.06 & -23.7 \\
\hline GC366 & $21.5-22.5$ & Erl-9295 & $\mathrm{AIO}$ & $20,224 \pm 312$ & 1294 & 2620 & $16,310 \pm 420$ & 0.06 & -24.4 \\
\hline GC359 & $0-1$ & Erl-9304 & $\mathrm{AIO}$ & $5131 \pm 50$ & 1294 & 3837 & $0 \pm 101$ & 0.70 & -25.8 \\
\hline GC359 & $24.5-25.5$ & Erl-9757 & $A I O$ & $11,736 \pm 120$ & 1294 & 3837 & $6605 \pm 221$ & 0.35 & -23.8 \\
\hline GC359 & $39.5-40.5$ & Erl-9305 & AIO & $34,345 \pm 1604$ & 1294 & 3837 & $29,214 \pm 1705$ & 0.20 & -25.7 \\
\hline GC359 & $64.5-65.5$ & Erl-9306 & $\mathrm{AIO}$ & $34,920 \pm 1700$ & 1294 & 3837 & $29,789 \pm 1801$ & 0.12 & -28.4 \\
\hline GC359 & $106.5-107.5$ & Erl-9307 & $\mathrm{AIO}$ & $41,792 \pm 3286$ & 1294 & 3837 & $36,661 \pm 3387$ & 0.25 & -29.2 \\
\hline GC358 & $24.5-25.5$ & Erl-10831 & AIO & $9570 \pm 82$ & 1294 & 3837 & $4439 \pm 183$ & 0.50 & -24.4 \\
\hline GC358 & $46.5-47.5$ & Erl-10832 & $\mathrm{AIO}$ & $13,076 \pm 95$ & 1294 & 3837 & $7945 \pm 196$ & 0.60 & -24.8 \\
\hline GC358 & $73.5-74.5$ & Erl-10833 & $A I O$ & $21,433 \pm 168$ & 1294 & 3837 & $16,302 \pm 269$ & 0.70 & -24.3 \\
\hline ВС356 & $0-1$ & Erl-6961 & F & $1913 \pm 55$ & 1294 & $\mathrm{~N} / \mathrm{A}$ & $619 \pm 106$ & $\mathrm{~N} / \mathrm{A}$ & 1.0 \\
\hline GC357 & $0-1$ & Erl-9296 & $\mathrm{AIO}$ & $6429 \pm 73$ & 1294 & 4516 & $619 \pm 124$ & 0.31 & -25.2 \\
\hline GC357 & $6.5-7.5$ & Erl-7872 & $\mathrm{F}$ & $5817 \pm 65$ & 1294 & $\mathrm{~N} / \mathrm{A}$ & $4523 \pm 189$ & $\mathrm{~N} / \mathrm{A}$ & 1.0 \\
\hline GC357 & $9.5-10.5$ & Erl-9760 & $A I O$ & $12,140 \pm 191$ & 1294 & 4516 & $6330 \pm 315$ & 0.11 & -24.8 \\
\hline GC357 & $15.5-16.5$ & Erl-9297 & $\mathrm{AIO}$ & $23,735 \pm 356$ & 1294 & 4516 & $17,925 \pm 480$ & 0.28 & -25.0 \\
\hline GC357 & $54.5-55.5$ & Erl-9298 & $\mathrm{AIO}$ & $41,814 \pm 3080$ & 1294 & 4516 & $36,004 \pm 3204$ & 0.22 & -25.3 \\
\hline ВС361Y & $0-1$ & Erl-10827 & $\mathrm{AIO}$ & $4450 \pm 68$ & 1294 & 3156 & $0 \pm 119$ & 0.40 & -24.5 \\
\hline GC360 & $14.5-15.5$ & Erl-10828 & $A I O$ & $8415 \pm 95$ & 1294 & 3156 & $3965 \pm 214$ & 0.30 & -24.4 \\
\hline GC360 & $34.5-35.5$ & Erl-10829 & $\mathrm{AIO}$ & $23,569 \pm 255$ & 1294 & 3156 & $19,119 \pm 374$ & 0.10 & -24.3 \\
\hline ВС369 & $0-1$ & Erl-6963 & $\mathrm{F}$ & $1947 \pm 54$ & 1294 & $\mathrm{~N} / \mathrm{A}$ & $653 \pm 105$ & $\mathrm{~N} / \mathrm{A}$ & 0.6 \\
\hline ВС369Y & $0-1$ & Erl-10018 & $\mathrm{AIO}$ & $6137 \pm 58$ & 1294 & 4190 & $653 \pm 109$ & 0.44 & -25.5 \\
\hline ВС $369 \mathrm{X}$ & $21.5-22.5^{\mathrm{a}}$ & Erl-7873 & $\mathrm{F}$ & $6069 \pm 71$ & 1294 & $\mathrm{~N} / \mathrm{A}$ & $4775 \pm 122$ & $\mathrm{~N} / \mathrm{A}$ & 0.1 \\
\hline GC368 & $23.5-24.5$ & Erl-9836 & $A I O$ & $25,240 \pm 565$ & 1294 & 4190 & $19,756 \pm 674$ & 0.06 & -24.6 \\
\hline GC368 & $34.5-35.5$ & Erl-9837 & $\mathrm{AIO}$ & $33,375 \pm 1223$ & 1294 & 4190 & $27,891 \pm 1332$ & 0.07 & -24.8 \\
\hline PS2533-2 & $1.5-2.5$ & Erl-6966 & $\mathrm{F}$ & $2499 \pm 56$ & 1294 & $\mathrm{~N} / \mathrm{A}$ & $1205 \pm 107$ & $\mathrm{~N} / \mathrm{A}$ & 0.8 \\
\hline PS2533-2 & $9.5-10.5$ & Erl-6967 & $\mathrm{F}$ & $4694 \pm 61$ & 1294 & $\mathrm{~N} / \mathrm{A}$ & $3400 \pm 112$ & N/A & 1.5 \\
\hline GC371 & $10-12$ & Erl-7875 & $\mathrm{F}$ & $3721 \pm 70$ & 1294 & $\mathrm{~N} / \mathrm{A}$ & $2427 \pm 121$ & $\mathrm{~N} / \mathrm{A}$ & 1.1 \\
\hline GC371 & $19.5-20.5$ & Erl-9761 & $\mathrm{AIO}$ & $32,527 \pm 1521$ & 1294 & 1170 & $30,063 \pm 1634$ & 0.13 & -26.0 \\
\hline GC371 & $28.5-29.5$ & Erl-9299 & $\mathrm{AIO}$ & $28,472 \pm 689$ & 1294 & 1170 & $26,008 \pm 802$ & 0.17 & -25.4 \\
\hline GC371 & $88.5-89.5$ & Erl-9300 & $\mathrm{AIO}$ & $22,507 \pm 436$ & 1294 & 1170 & $20,043 \pm 549$ & 0.17 & -26.5 \\
\hline ВС373 & $0-1$ & Erl-6964 & $\mathrm{F}$ & $3354 \pm 57$ & 1294 & $\mathrm{~N} / \mathrm{A}$ & $2060 \pm 108$ & $\mathrm{~N} / \mathrm{A}$ & 2.3 \\
\hline BC373Y & 0-1 & Erl-10224 & $\mathrm{AIO}$ & $3791 \pm 66$ & 1294 & 437 & $2060 \pm 117$ & 0.28 & -24.5 \\
\hline GC372 & $21.5-22.5$ & Erl-10225 & $A I O$ & $27,900 \pm 797$ & 1294 & 437 & $26,169 \pm 914$ & 0.07 & -24.8 \\
\hline GC372 & $93.5-94.5$ & Erl-10226 & $\mathrm{AIO}$ & $34,401 \pm 1550$ & 1294 & 437 & $32,670 \pm 1667$ & 0.10 & -25.5 \\
\hline GC372 & $103.5-104.5$ & Erl-10227 & $\mathrm{AIO}$ & $40,552 \pm 2916$ & 1294 & 437 & $38,821 \pm 3033$ & 0.16 & -25.6 \\
\hline GC374 & $0-1$ & Erl-9301 & AIO & $4524 \pm 62$ & 1294 & 1170 & $2060 \pm 113$ & 0.27 & -24.8 \\
\hline GC374 & 9-10 & Erl-7874 & $\mathrm{F}$ & $4063 \pm 64$ & 1294 & $\mathrm{~N} / \mathrm{A}$ & $2769 \pm 115$ & $\mathrm{~N} / \mathrm{A}$ & 1.3 \\
\hline GC374 & $11.5-12.5$ & Erl-9762 & $A I O$ & $27,512 \pm 721$ & 1294 & 1170 & $25,048 \pm 834$ & 0.04 & -25.7 \\
\hline GC374 & $27.5-28.5$ & Erl-9302 & $\mathrm{AIO}$ & $33,916 \pm 2146$ & 1294 & 1170 & $31,452 \pm 2259$ & 0.07 & -25.3 \\
\hline GC374 & $92.5-93.5$ & Erl-9303 & $\mathrm{AIO}$ & $40,138 \pm 3662$ & 1294 & 1170 & $37,674 \pm 3775$ & 0.16 & -25.6 \\
\hline BC355 & $0-1$ & Erl-6960 & $\mathrm{F}$ & $6602 \pm 61$ & 1294 & $\mathrm{~N} / \mathrm{A}$ & $5308 \pm 112$ & $\mathrm{~N} / \mathrm{A}$ & 2.4 \\
\hline
\end{tabular}

a Sample depth of $21.5-22.5 \mathrm{cmbsf}$ in box core BC369X was correlated with a depth of $11.0-12.0 \mathrm{cmbsf}$ in gravity core GC368 by splicing the CaCO 3 records of the two cores.

The $\mathrm{C}_{\text {org }}$ contents of the dated samples from the southern Bellingshausen Sea shelf range from 0.04 to 0.70 wt.\% (Table 1). In general, the samples with low $\mathrm{C}_{\text {org }}$ contents have older $\mathrm{AIO}^{14} \mathrm{C}$ ages (Fig. 8a). However, these samples were taken from the gravelly sandy muds and diamictons, i.e. from sediments that are stratigraphically older and have a mainly terrigenous composition (Fig. 2). Among samples taken exclusively from mainly terrigenous sediments no systematic relationship between AIO ${ }^{14} \mathrm{C}$ ages and $\mathrm{C}_{\text {org }}$ contents is evident (Fig. 8a). The same applies to samples exclusively taken from diatom- and foraminifera-bearing sediments of the upper lithological unit (Fig. 8a).

The $\mathrm{C}_{\text {org }} / \mathrm{N}_{\text {tot }}$ ratios in most diamictons and the lower part of the gravelly sandy muds exceed 10 and thus are relatively high (Fig. 2). However, it remains unclear, if these high ratios result from enhanced supply of fossil, terrestrial plant material or marine benthic algal material in combination with nitrogen limitation caused by ice coverage (see Section 3.4). The $\delta^{13} C_{\text {org }}$ ratios of the radiocarbon-dated organic material from the southern Bellingshausen Sea vary mainly between $-23.7 \%$ and $-26.5 \%$ o (Table 1 ; Fig. 8b). Only in core GC359 the two lowermost samples taken from the lower and the middle lithological unit exhibit strongly depleted $\delta^{13} C_{\text {org }}$ ratios of $-29.2 \%$ and $-28.4 \%$, respectively. With the exception of site GC359, the down-core variability of the $\delta^{13} C_{\text {org }}$ values at each individual core site is $\leq 1.1 \%$ o (Table 1 ), which is comparable or less than at core sites from other parts of the Antarctic shelf (e.g. Harden et al., 1992; Domack et al., 1998, 1999, 2001; Licht and Andrews, 2002; Ó Cofaigh et al., 2005a; Pudsey et al., 2006; Hemer et al., 2007; McKay et al., 2008; Hillenbrand et al., 2010). The $\delta^{13} C_{\text {org }}$ composition of marine particulate organic substance typically ranges from $-18 \%$ to $-27 \%$ (e.g. Harden et al., 1992; Meyers, 1997; Lamb et al., 2006; Smith et al., 2006). More depleted $\delta^{13} \mathrm{C}_{\text {org }}$ values down to $-29.4 \%$ o were reported for the organic material in sediments from the Ross Sea shelf (Andrews et al., 1999; Domack et al., 1999). These very low $\delta^{13} C_{\text {org }}$ values are attributed to the occurrence of the prymnesiophyte Phaeocystis antarctica (Ohkouchi and Eglinton, 2006), which is a major phytoplankton primary producer in the Ross Sea and around the Antarctic Peninsula (e.g. Abelmann et al., 2006). With the exception of the two $\delta^{13} \mathrm{C}_{\mathrm{org}}$-depleted samples from core GC359, the $\delta^{13} \mathrm{C}_{\text {org }}$ ratios in the samples from the southern Bellingshausen 


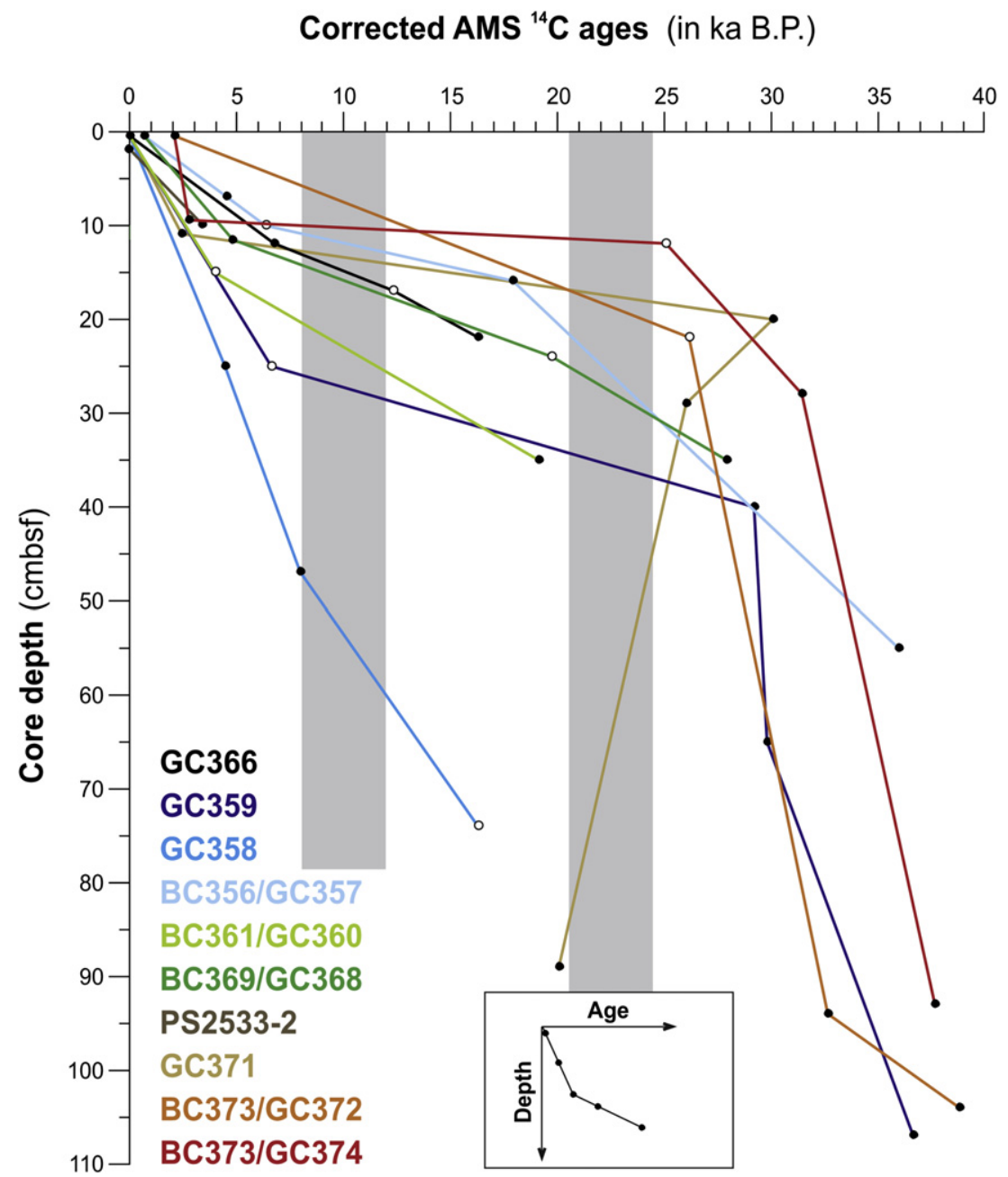

Fig. 7. Age-depth plots for the sediment cores from the southern Bellingshausen Sea shelf. The profiles are based on corrected AMS ${ }^{14} \mathrm{C}$ dates that are indicated by the black and open dots. The ${ }^{14} \mathrm{C}$ ages that provide the most reliable ages for ice-sheet retreat are indicated by the open dots. The inset illustrates a hypothetical age-depth profile with a typical "dog leg" caused by the higher down-core contamination with recycled fossil organic matter. The grey bars mark gaps in the obtained ${ }^{14} \mathrm{C}$ dates (see Section 4.2 .3 ).

Sea shelf suggest that the radiocarbon-dated organic matter is predominantly of marine origin. Importantly, no obvious systematic link exists between the uncorrected $\mathrm{AIO}{ }^{14} \mathrm{C}$ dates and the $\delta^{13} \mathrm{C}_{\text {org }}$ ratios of the organic substance, if the two $\delta^{13} \mathrm{C}_{\text {org }}$-depleted samples from core GC359 are not considered (Fig. 8b).

\section{Discussion}

\subsection{Sedimentary facies and depositional environments}

\subsubsection{Subglacial facies and proximal grounding-line facies}

We have previously classified the sediments of the lower lithological unit as subglacial soft tills (GC357, GC359, GC360, GC362, GC368, GC370, GC372, GC374), sub-ice shelf diamictons (GC357, GC359, GC360, GC362, GC365, GC366, GC368, GC370, GC372, GC374), glaciogenic debris flows (GC352, GC365, GC366), icebergrafted diamictons (GC362, GC365, GC366, GC368) and iceberg turbate (GC371), respectively, mainly based on their continuously terrigenous and coarse-grained lithology, shear strength values and homogenous clay mineral composition (Hillenbrand et al., 2005, 2009). Here, we refine this classification by taking into account the additional physical properties and grain-size data and the sedimentary structures (Table 2). Our interpretations are largely consistent with published facies classifications from elsewhere on the Antarctic shelf (e.g. Kurtz and Anderson, 1979; Anderson et al., 1980; Wright and Anderson, 1982; Licht et al., 1996, 1998, 1999; Domack et al., 1998, 1999, 2005; Anderson, 1999; Pudsey and Evans, 2001; Wellner et al., 2001; Evans and Pudsey, 2002; Brachfeld et al., 2003; Evans et al., 2005; Heroy and Anderson, 2005; Hillenbrand et al., 2005, 2010; Ó Cofaigh et al., 2005a; Mosola and Anderson, 2006; Pudsey et al., 2006; McKay et al., 2008; Smith et al., 2009).

We interpret muddy diamictons of the lower lithological unit, which are characterised by medium to high shear strength values, low $\mathrm{CaCO}_{3}$ contents and only minor fluctuations in MS, water content, WBD and grain-size composition, as subglacial soft tills (ST) deposited at the base of the ice stream that had advanced through Belgica Trough (Table 2, Fig. 2). For cores GC359 and GC374, this interpretation is corroborated by the observed shear planes (Fig. 3) that resemble structures reported from soft tills on the western and eastern Antarctic Peninsula shelf (Evans et al., 2005; Ó Cofaigh et al., 2005a, 2007). In contrast, we assign muddy diamictons, which do not fulfill these criteria and overly the soft tills (Table 2, Fig. 2), to a sub-ice shelf setting (SIS prox) proximal to the grounding line of the retreating ice stream. In such a depositional environment sediment is mainly delivered by melt-out of basal debris near the grounding line with minor advection of finegrained particles by ocean currents. Variability in sediment supply 
a

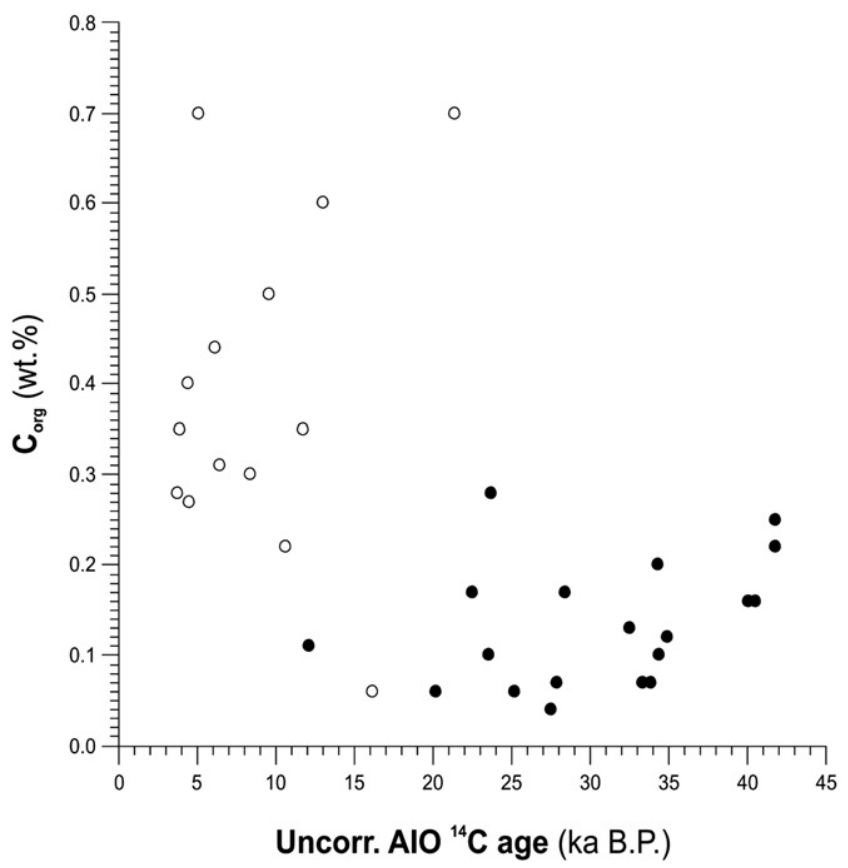

b

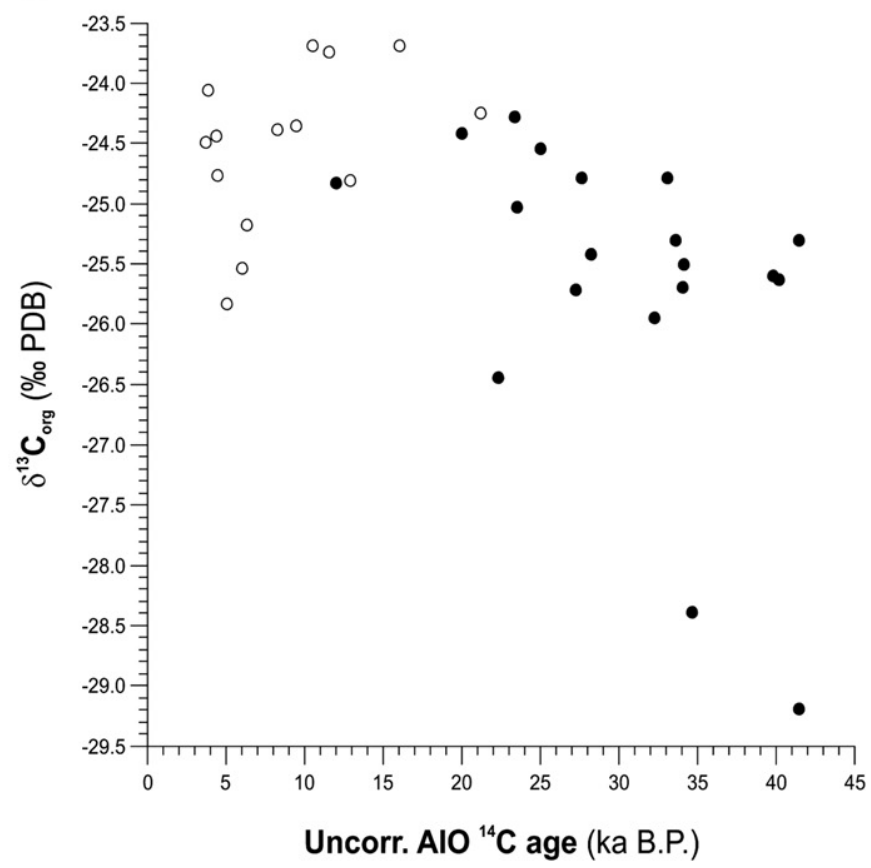

Fig. 8. Uncorrected AMS ${ }^{14} \mathrm{C}$ ages of the AIO versus $C_{\text {org }}$ content (a) and the $\delta^{13} C_{\text {org }}$ composition of the organic material (b). Samples from the biogenic-bearing sediments of the upper lithological unit are highlighted by open circles and those from the mainly terrigenous sediments of the middle and lower lithological units are marked by filled circles.

and current-induced sorting is reflected in the muddy diamictons of our cores by the variability of physical properties and grain-size composition (cf. Domack et al., 1998, 1999; Licht et al., 1999; Evans and Pudsey, 2002; Hillenbrand et al., 2005). In the upper muddy diamicton of core GC374 we observe a stratified interval (Fig. 2), which is considered to be characteristic for glaciomarine diamictons (e.g. Domack et al., 1998; Licht et al., 1999; Evans and Pudsey, 2002; Ó Cofaigh et al., 2005a, 2008).

The only exceptions in the assignment of muddy diamictons with low to medium shear strength to a proximal sub-ice shelf setting are cores GC352 and GC371 (Fig. 2). Core GC352 was recovered from a water depth of $718 \mathrm{~m}$ just beyond the shelf break. We therefore interpret its muddy diamicton as a glaciogenic debris flow (GDF) and iceberg-rafted sediment (IS), respectively (Table 2). The debris flow was deposited, when subglacial debris released at the grounding line of the ice stream in Belgica Trough was redeposited down-slope (Hillenbrand et al., 2005, 2009; Dowdeswell et al., 2008a). Core GC371 was collected from an iceberg-furrowed area in outer Belgica Trough (Ó Cofaigh et al., 2005b). Therefore, we interpret the upper diamicton at this site as an iceberg turbate (IT), while we classify the lower diamicton as a soft till (Table 2). Our interpretation is supported by the inverse radiocarbon stratigraphy at site GC371 (Table 1, Fig. 2).

The lower lithological unit at several sites, mainly from the inner shelf, comprises gravelly diamictons with variable, in most cases low to medium shear strength values (Fig. 2). We classify the gravelly diamictons at sites GC365, GC366, GC368 and GC372 as proximal grounding-line sub-ice shelf sediments (SIS prox), because they also show variable MS, WBD and water contents (Table 2; cf. Domack et al., 1999; Evans et al., 2005). Core GC365 from Eltanin Bay additionally bears gravelly diamicton with relatively constant WBD and MS values at its base. The clay mineralogical signature of this lower gravelly diamicton differs from that in the upper gravelly diamicton by the presence of smectite, and thus resembles the clay mineral assemblage of the upper lithological unit (Fig. 2), which suggests sediment supply from various, more distal sources (cf. Hillenbrand et al., 2009). Therefore, we interpret the lower gravelly diamicton at site GC365 as iceberg-rafted sediment (IS; Table 2). The same interpretation is preferred for the gravelly diamicton at site GC362, which is also characterised by relatively constant WBD and MS values.

The $\mathrm{CaCO}_{3}$ content in the lower lithological unit is $\sim 1 \mathrm{wt} . \%$, while the $\mathrm{C}_{\text {org }}$ content ranges from $\sim 0.05$ to $0.10 \mathrm{wt} . \%$ in the gravelly diamictons to $0.10-0.25 \mathrm{wt}$.\% in the muddy diamictons. Assuming that both the organic and inorganic carbon is of biogenic origin, the significant $\mathrm{C}_{\text {org }}$ and $\mathrm{CaCO}_{3}$ concentrations in the diamictons suggest considerable subglacial reworking of older interglacial shelf sediments (cf. Domack et al., 1999) and/or fossil biogenic sedimentary strata (cf. Nishimura et al., 1999; Pudsey and Evans, 2001). This detritus was apparently incorporated into the till at the base of the ice stream and the derived proglacial sediments.

\subsubsection{Distal sub-ice shelf/sub-sea ice facies}

The predominantly terrigenous composition, the general lack of bioturbation and the high variability of grain-size composition and physical properties in the middle lithological unit (Fig. 2) indicate its deposition in a glaciomarine environment under an ice-shelf distal from the grounding line or under permanent sea-ice coverage (cf. Hillenbrand et al., 2005, 2009). This interpretation is in agreement with the relatively high $\mathrm{C}_{\text {org }} / \mathrm{N}_{\text {tot }}$ ratios of this unit, which may result from nitrogen limitation in response to ice cover (e.g. McMinn et al., 2001; Yoon et al., 2010). In cores GC358, GC359, GC360, GC362, GC370, GC371, GC372 and PS2533-2 the increasing influence of seasonal open-water conditions towards the top of the gravelly sandy mud is reflected by an increase of $\mathrm{C}_{\text {org }}$ and/or $\mathrm{CaCO}_{3}$ concentrations, the onset of bioturbation and/or the increase of silt and clay contents (Fig. 2; Hillenbrand et al., 2005). At sites GC357, GC359, GC360, GC368, GC370, GC372 and GC374 the transition to more open-marine conditions is also suggested by the drop of the $\mathrm{C}_{\text {org }} / \mathrm{N}_{\text {tot }}$ ratios to values $\leq 10$ towards the top of the gravelly sandy mud unit (Fig. 2), because such ratios are typical for marine phytoplankton production in open water (e.g. Meyers, 1997; Lamb et al., 2006). 


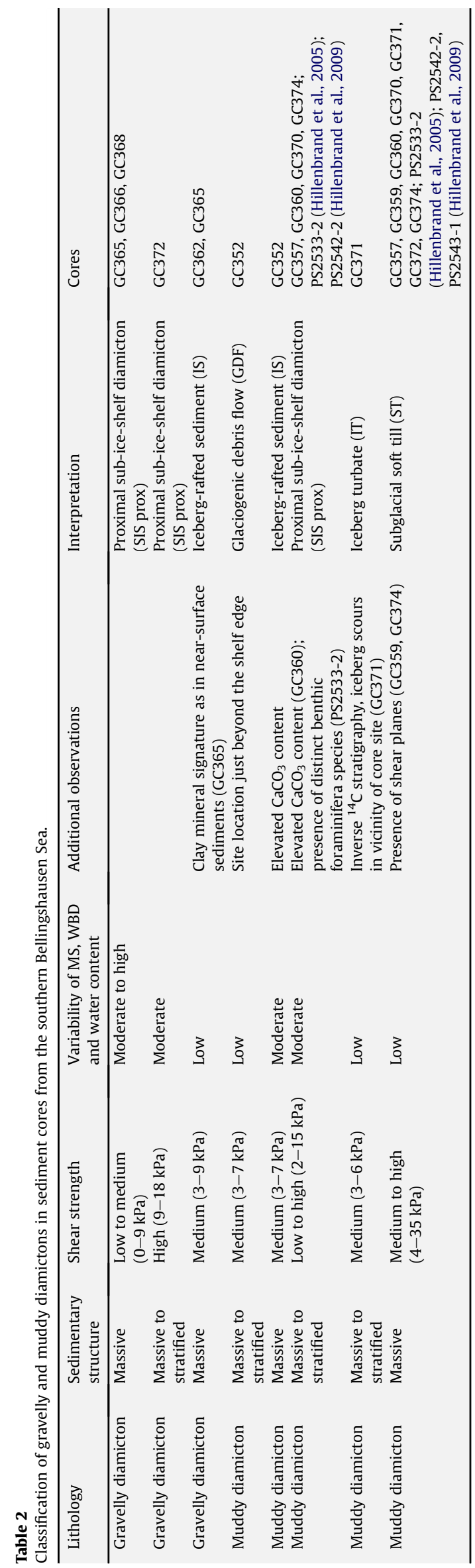

At site GC359 the lower part of the middle lithological unit differs from the upper part by maxima in gravel content and MS, high WBD variability, a minimum in water content and a stratified interval (Fig. 2). Therefore, we assign this lower part of the gravelly sandy mud to a more proximal sub-ice shelf setting. In core GC362 the middle lithological unit is expanded, shows a high variability of MS, WBD, water content and gravel content (Fig. 2) and contains a mud clast (Fig. 3). Also these characteristics point to a depositional setting in relative proximity to the grounding line. The middle lithological unit at site GC371 exhibits an inverse ${ }^{14} \mathrm{C}$ stratigraphy (Table 1 ) suggesting that the gravelly sandy mud is part of the iceberg-turbated sequence (Fig. 2). The present water depth at site GC371 is $595 \mathrm{~m}$, corresponding to an LGM water depth of $\sim 465 \mathrm{~m}$ (assuming no significant glacio-isostatic depression of the outer shelf). The modern maximum iceberg-keel depth in the study area is only 150-200 m (Ferrigno et al., 1998; Dowdeswell and Bamber, 2007). Thus, the iceberg scouring near site GC371 is more likely to have occurred during the last deglaciation, when the APIS and the WAIS calved much larger icebergs.

The middle lithological unit was apparently deposited during the transition from a subglacial/proximal grounding-line setting to a seasonal open-marine environment (cf. Hillenbrand et al., 2005, 2009). This transition is particularly evident from the clay mineral assemblages (Fig. 2). At most sites (GC352, GC359, GC368, GC370, GC372, GC374, PS2533-2; Fig. 2, Hillenbrand et al., 2005, 2009) the clay mineral composition of the middle lithological unit changes from an assemblage resembling that of the underlying diamictons to an assemblage similar to that of the overlying foraminifera- or diatom-bearing muds. In some cores, however, the clay mineral assemblage of the gravelly sandy muds is rather distinct (e.g. GC357, GC360, GC362, GC371, PS2542-2; Fig. 2, Hillenbrand et al., 2009), which we attribute to the time-transgressive deglaciation of the various source areas for the clay mineral assemblages (for details see Fig. 15 in Hillenbrand et al., 2009).

\subsubsection{Seasonal open-marine facies}

We previously classified the upper lithological unit as a seasonal open-marine facies based on its microfossil content, its bioturbation and its mixed clay mineralogical composition (Hillenbrand et al., 2005, 2009). Such a glaciomarine setting, which prevails in the southern Bellingshausen Sea today, is characterised by deposition of terrigenous detritus supplied by icebergs and tidal- and wind-driven currents from a relatively wide source area in the West Antarctic hinterland and of planktonic microfossils, such as diatoms and foraminifera (cf. Hillenbrand et al., 2003, 2005, 2009). The elevated $C_{\text {org }}$ concentrations of the upper lithological unit across the shelf, together with the high $\mathrm{CaCO}_{3}$ contents at sites on the middle to outer shelf and from beyond the shelf break (Figs. 2, 4), support the interpretation of the upper lithological unit as a seasonal open-marine facies.

The highest $\mathrm{C}_{\text {org }}$ contents occur in the upper lithological unit of cores located in the southern part of the study area. This geographical pattern probably results from i) high sedimentation rates at these core sites, which are indicated by the young uncorrected ${ }^{14} \mathrm{C}$ ages obtained from the calcareous (micro-)fossils and/or the high excess ${ }^{210} \mathrm{~Pb}$ concentrations in the surface sediments (Figs. 4,6), ii) significant concentrations of diatoms in the sediments on the inner shelf, and iii) high mud contents at those core sites (>80 wt.\%; Fig. 2). Higher sedimentation rates may be the most important factor because they favour the preservation of both $C_{\text {org }}$ and diatom frustules (e.g. DeMaster et al., 1996). Diatom frustules contain large amounts of organic matter and are mainly silt sized, i.e. they may also contribute to a fine grain-size of the sediment. 
The observed seaward increase of calcareous foraminifera, $\mathrm{CaCO}_{3}$ and terrigenous sand contents in the surface sediments, which coincides with an seaward increase of the ${ }^{14} \mathrm{C}$ ages of calcareous (micro-)fossils (Fig. 4), probably results from sediment condensation and/or non-deposition on the middle-outer shelf and the upper continental slope in response to current-induced winnowing (cf. Hillenbrand et al., 2003). We have assumed that the regional MRE is given by the conventional ${ }^{14} \mathrm{C}$ age of 1294 yrs B.P. obtained from a scaphopod at site BC364/GC365 in Eltanin Bay (see Section 2). This assumption is validated by the high excess ${ }^{210} \mathrm{~Pb}$ concentration at site BC364 indicating modern sedimentation (Fig. 6). On the middle shelf, the ${ }^{14} \mathrm{C}$ ages obtained from planktonic foraminifera exceed the regional MRE by $\sim 600$ years (Fig. 4). However, the excess ${ }^{210} \mathrm{~Pb}$ profile at site BC369/GC368 indicates modern sedimentation (Fig. 6) on the middle shelf. Therefore, we attribute the slightly older ${ }^{14} \mathrm{C}$ ages to a condensation effect (about 1000-2000 foraminifera tests per sample were picked for radiocarbon dating, and the tests from the base of this $1 \mathrm{~cm}$-thick sample are likely to be older than those from the top of the sample). The foraminiferal ${ }^{14} \mathrm{C}$ ages from the outer shelf and upper slope exceed the MRE even more, by $\sim 2000-5300$ yrs (Fig. 4). However, the excess ${ }^{210} \mathrm{~Pb}$ profile at site BC373/GC372 (Fig. 6) suggests that these old ${ }^{14} \mathrm{C}$ ages of the seabed surface are caused by sediment condensation rather than by non-deposition or erosion. Condensation caused by winnowing is also indicated by the high abundance of manganese-coated, coarse-grained IRD on the outer shelf (Supplementary Figure 1b), because formation of manganese crusts requires sedimentation rates of $\leq 1 \mathrm{~mm} / \mathrm{ka}$ (e.g. Roy, 1981).

Because the Antarctic Slope Front is not present in the study area, the only geostrophic current that may have reduced the sedimentation rates on the middle-outer shelf and the upper continental slope by winnowing is a current associated with the SBACC. The SBACC, which runs along the shelf break today, may have repeatedly swept onto the shelf of the southern Bellingshausen Sea during the last few thousand years (cf. Hillenbrand et al., 2003). Such southward shifts of the SBACC would also have advected more CDW onto the shelf (e.g. Walker et al., 2007), which may have resulted in enhanced oceanic melting of ice shelves and glaciers along the coast (cf. Jacobs et al., 1996). The location of the SBACC may actually be constrained by the shelf break itself (Orsi et al., 1995; Jenkins and Jacobs, 2008). Similar as in the Amundsen Sea embayment (Thoma et al., 2008), seasonal changes in the wind system may have caused stronger deep-water advection onto the shelf of the southern Bellingshausen Sea and thus winnowing of the sediments.

\subsection{Reconstruction of the ice-sheet history on the southern Bellingshausen Sea shelf}

All ${ }^{14} \mathrm{C}$ dates mentioned in this section, including those taken from the literature, are reported as corrected, uncalibrated ${ }^{14} \mathrm{C}$ ages. The two oldest AIO ${ }^{14} \mathrm{C}$ dates from core GC359 are not considered because of the extremely depleted $\delta^{13} \mathrm{C}_{\text {org }}$ ratios of the corresponding samples, which may indicate extremely high contamination with fossil carbon (see Section 3.7.3).

\subsubsection{Timing of ice-sheet advance}

We have obtained $\mathrm{AIO}{ }^{14} \mathrm{C}$ ages from the subglacial tills (GC357, GC372) and the proximal grounding-line diamictons (GC372, GC374). The corrected ages from the soft tills range from 38.8 ka B.P. (GC372) to 36.0 ka B.P. (GC357), while those from the sub-ice shelf diamictons have similar or slightly younger ages between $37.7 \mathrm{ka} \mathrm{B}$. P. (GC374) and 32.7 ka B.P. (GC372) (Table 1, Fig. 2). The ${ }^{14} \mathrm{C}$ dates from the subglacial diamictons have to be considered as maximum ages for the ice-sheet advance across the shelf, because the ice probably eroded older, interglacial shelf sediments at its base and incorporated their organic matter into the till (cf. Licht et al., 1996, 1999; Domack et al., 1999; Heroy and Anderson, 2007). Subglacial recycling of fossil biogenic material is indicated for the tills from the southern Bellingshausen Sea by both their $\mathrm{C}_{\text {org }}$ contents (and possibly also their $\mathrm{CaCO}_{3}$ contents; Fig. 2) and their high $\mathrm{C}_{\mathrm{org}} / \mathrm{N}_{\text {tot }}$ ratios. Reworking of old sedimentary detritus into the diamictons is also evident from their clay mineral composition (see Hillenbrand et al., 2009). At each core site the clay mineral assemblage of the soft till and the overlying proximal grounding-line diamicton is very similar (Figs. 2, 9; Hillenbrand et al., 2009), which may also explain their similar AIO radiocarbon ages. We attribute the relatively young ${ }^{14} \mathrm{C}$ age of the sub-ice shelf diamicton at site GC372 to the dilution of the old, reworked organic matter with some fresh organic carbon advected from open-water areas beyond the iceshelf front into the ice-shelf cavity (cf. Licht et al., 1996, 1999; Domack et al., 1999; Hemer et al., 2007).

We conclude that the last ice-stream advance through Belgica Trough must have occurred after 36.0 ka B.P. and possibly later than 32.7 ka B.P. These ages pre-date corrected ${ }^{14} \mathrm{C}$ ages for the advance of the APIS across the outer shelf west of the Antarctic Peninsula ( 15.5 ka B.P., Nishimura et al., 1999) and of the WAIS across the outer shelf of the western Ross Sea ( 27.0-26.5 ka B.P., Domack et al., 1999; Emslie et al., 2007), the inner shelf of the central Ross Sea ( 17.8 ka B.P., Licht and Andrews, 2002) and the outer shelf of the central-eastern Ross Sea ( 21.0 ka B.P., Mosola and Anderson, 2006; 13.8 ka B.P., Licht and Andrews, 2002).

\subsubsection{History of ice-sheet retreat}

The time of the post-LGM ice-sheet retreat from the Antarctic shelf is often determined by dating the base of the post-glacial biogenic sediments, i.e. by dating the onset of seasonal openmarine sedimentation (e.g. Pudsey et al., 1994; Licht et al., 1996, 1999; Domack et al., 1999, 2001; Anderson et al., 2002; Licht and Andrews, 2002; Heroy and Anderson, 2005; Mosola and Anderson, 2006; McKay et al., 2008). These dates actually provide only minimum ages for ice-sheet retreat, but they are considered to be the most reliable radiocarbon ages available. This is because the underlying terrigenous transitional sediments deposited more proximal to the retreating grounding line usually lack calcareous microfossils, while the organic carbon contents in these transitional sediments are subject to significant contamination with subglacially reworked, fossil organic matter (e.g. Domack, 1992; Domack et al., 1999; Heroy and Anderson, 2007; Rosenheim et al., 2008; Hillenbrand et al., 2010). In age-depth profiles for sediment cores, this higher degree of down-core contamination is visible as a pronounced kink, sometimes referred to as a "dog leg" (Fig. 7 inset; e.g. Licht et al., 1998; Heroy and Anderson, 2007).

In the cores from the middle and outer shelf of the southern Bellingshausen Sea the corrected ${ }^{14} \mathrm{C}$ ages obtained from calcareous foraminifera tests are not older than 4.8 ka B.P., with the oldest age occurring at site BC369/GC368 on the middle shelf (Table 1, Fig. 2). These ages that mark the post-LGM onset of biological productivity are very young and therefore unsuitable for constraining initial icesheet retreat in our study area. On the other hand, the corrected AIO ${ }^{14} \mathrm{C}$ ages from the middle lithological unit, which comprises the transitional sediments deposited subsequent to grounding-line retreat, drastically increase down-core at most of the core sites (Table 1, Fig. 2) and apparently exhibit dog legs in age-depth profiles (Fig. 7).

In order to evaluate the reliability of the $\mathrm{AIO}{ }^{14} \mathrm{C}$ ages for icestream retreat in Belgica Trough we used the information about changes in sediment provenance provided by the changes in clay mineral assemblages (Fig. 2; Hillenbrand et al., 2009). We expect these changes in clay mineralogy to reflect variations in the degree 

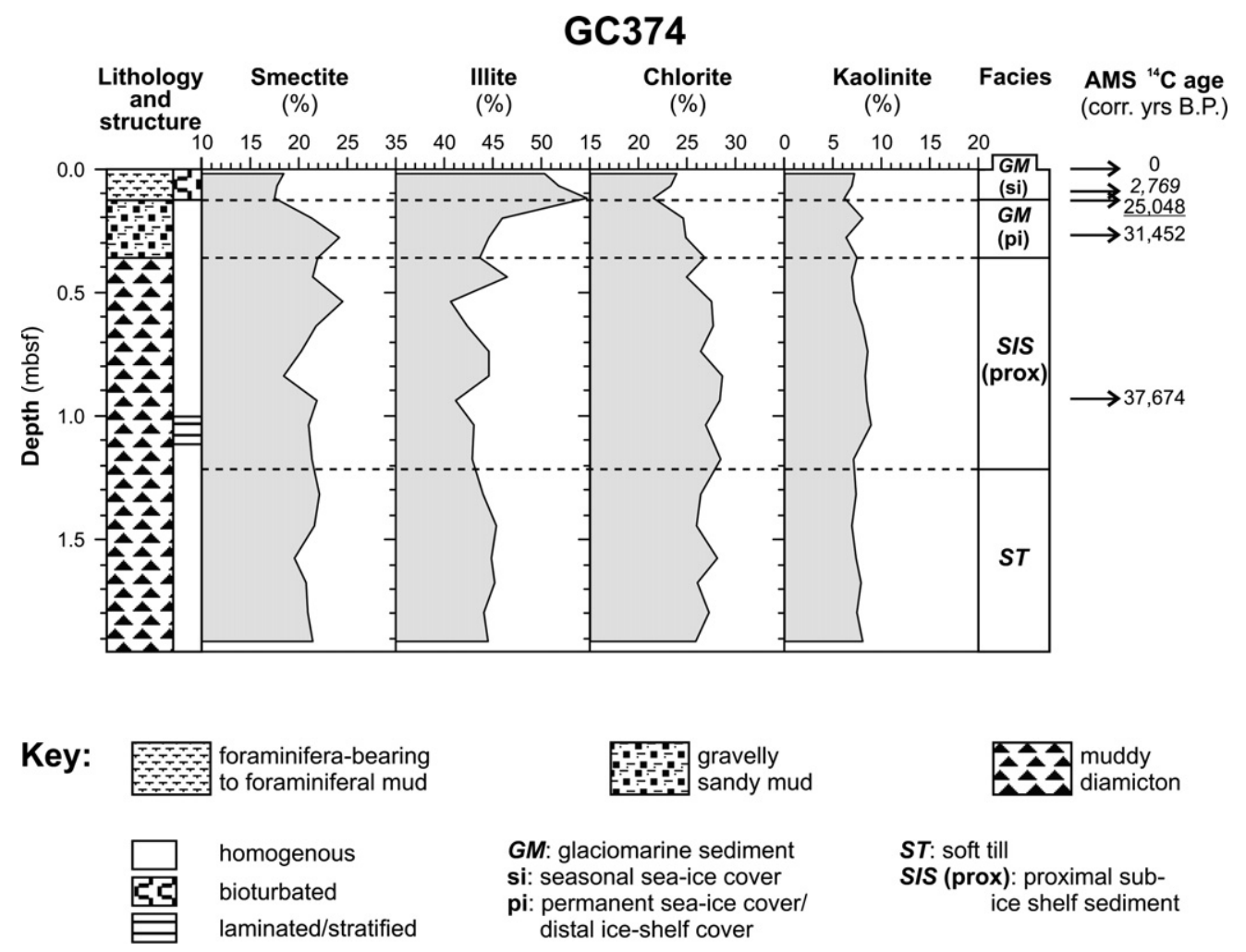

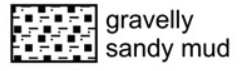

GM: glaciomarine sediment si: seasonal sea-ice cover pi: permanent sea-ice cover/ distal ice-shelf cover

Fig. 9. Lithology, sedimentary structures, clay mineral composition, facies interpretation and corrected AMS ${ }^{14} \mathrm{C}$ dates for core GC374 demonstrating the identification of the most reliable ${ }^{14} \mathrm{C}$ age (underlined) for ice-stream retreat (cf. Fig. 2). This ${ }^{14} \mathrm{C}$ date was obtained from the part of the gravelly sandy mud unit, whose clay mineral assemblage resembles that of the foraminifera-bearing sediments.

of contamination with fossil carbon and/or in the age of the contaminating organic matter. We consider that the most reliable down-core AIO ${ }^{14} \mathrm{C}$ ages are those, which were obtained from sediments with a clay mineral composition resembling that of the open-marine sediments (Fig. 9). These ages are obtained either from the base of the seasonal open-marine facies or the upper part of the distal sub-ice shelf/sub-sea ice facies. The similarity in provenance of the corresponding samples may justify the correction of their AIO ${ }^{14} \mathrm{C}$ dates by simply subtracting the MRE and the LCO inferred from the seafloor surface sediments. In contrast, we expect all dates from the base of the middle lithological unit to be unreliable, because they were obtained from sediments with a "glacial" provenance. As a consequence of changes in the icestream catchment and subglacial reworking of older shelf sediments during the last glacial period (Hillenbrand et al., 2009), this provenance is different from the provenance of the Holocene and modern sediments. Therefore, the dates from the base of the middle lithological unit are likely to be overprinted by a higher contamination with older fossil carbon (Fig. 9).

Following this concept, we reconstructed the post-LGM icesheet retreat from the outer (sites GC374, GC372), middle (site GC368) and the inner shelf in the southern Bellingshausen Sea (sites GC357, GC360 and GC366) (Fig. 10). All these cores sites are located on palaeo-flow lines of ice feeding into and flowing through Belgica Trough (see Fig. 1). In the samples that we consider to provide the most reliable ages for ice-stream retreat (Fig. 2), the $\delta^{13} C_{\text {org }}$ ratios of the organic matter are $\geq-25.7 \%$ (Table 1 ). Apart from cores GC368 and GC372, the $\mathrm{C}_{\text {org }} / \mathrm{N}_{\text {tot }}$ ratios of the corresponding sediments are $\leq 10$ (Fig. 2). Thus, the $\delta^{13} \mathrm{C}_{\text {org }}$ and $\mathrm{C}_{\text {org }} / \mathrm{N}_{\text {tot }}$ ratios suggest a predominantly marine origin of the dated organic material in most of the selected samples (see Sections 3.4. and 3.7.3). According to our chronology, the outer shelf deglaciated at $\sim 25.5 \mathrm{kaB}$.P. and the grounding line of the ice stream then retreated slowly towards the mid-shelf, which was ice-free by $\sim 19.8$ ka B.P. (Fig. 10). Grounding-line retreat towards the inner shelf in Eltanin Bay then continued at a similar rate, and site GC366 became ice-free at $\sim 12.3 \mathrm{ka}$ B.P. The rate of ice retreat from site GC366 towards the present WAIS grounding line apparently was slower (Fig. 10a).

Ice-stream retreat from the middle shelf towards Ronne Entrance shows a different pattern. Site GC357 in northern Ronne Entrance did not become ice-free until 6.3 ka B.P. (Fig. 10b). Afterwards, the ice stream retreated more rapidly to site GC360, which became ice-free at $\sim 4.0$ ka B.P., and then to the modern ice front of the George VI Ice Shelf (Fig. 10b). The slow-down of ice-stream retreat from site GC368 to site GC357 and its apparent acceleration to site GC360 may have been controlled by the shelf bathymetry because a bathymetric high is located seaward of site GC357 (indicated by the $600 \mathrm{~m}$ water depth contour in Fig. 1), while a deep basin is located just to the north of site GC360 (indicated by the $800 \mathrm{~m}$ water depth contour in Fig. 1). The palaeo-ice stream in Belgica Trough was marine-based, and therefore an inverse bed slope may have accelerated the retreat of its grounding line (e.g. Thomas and Bentley, 1978; Oppenheimer, 1998; Schoof, 2007; Vaughan and Arthern, 2007).

Our chronology for ice-stream retreat is consistent with the minimum age of 20.0 ka B.P. for the iceberg scouring of site GC371 (Table 1, Fig. 2). Comparison of our preferred deglaciation chronology with the chronology based on the corrected AIO ${ }^{14} \mathrm{C}$ ages from the lower part of the distal sub-ice shelf/sub-sea ice facies reveals similar patterns (Fig. 10). However, the ages in the latter chronology are several thousand years older and exhibit an inconsistency for ice-stream retreat from site GC357 to site GC360 (Fig. 10). Therefore, we consider those ages to be too old and unreliable for recording ice-sheet retreat. 

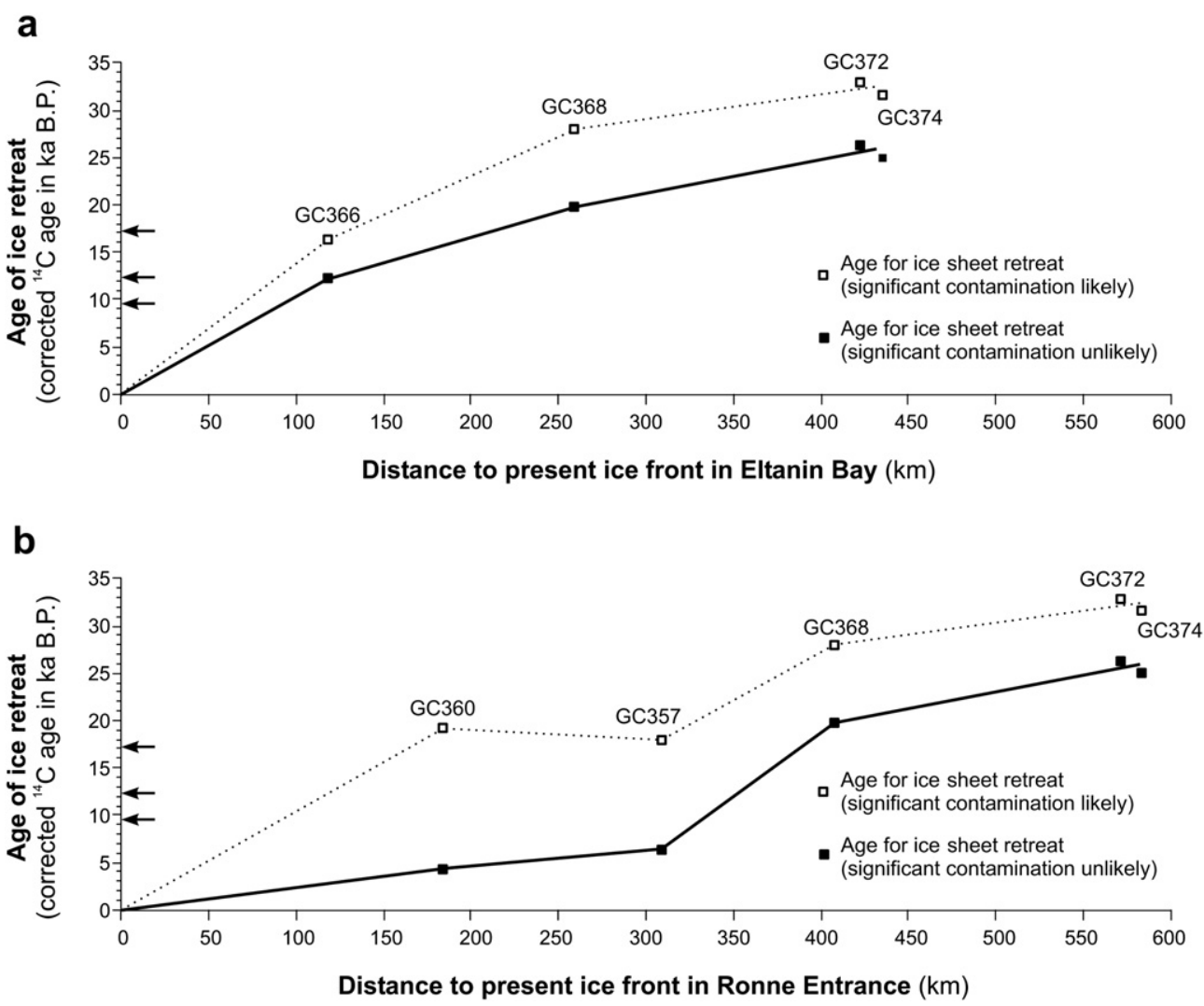

Fig. 10. Profiles for ice-stream retreat from the outer shelf of the southern Bellingshausen Sea towards the modern WAIS grounding line in Eltanin Bay (a) and the modern front of the George VI Ice Shelf in Ronne Entrance (b). The continuous profiles are based on corrected AMS ${ }^{14} \mathrm{C}$ dates, which are unlikely to be contaminated by reworked fossil organic carbon, and therefore provide the most reliable chronology of ice-sheet retreat from the shelf. The dashed profiles are based on corrected ${ }^{14} \mathrm{C}$ ages from the base of the transitional sedimentary unit. These dates are likely to be significantly contaminated with recycled fossil organic matter and therefore provide unreliable ages for deglaciation. The arrows indicate corrected ${ }^{14} \mathrm{C}$ ages of global meltwater pulses (Fairbanks, 1989; Clark et al., 2002, 2004).

Our preferred chronology for the ice-sheet retreat from the southern Bellingshausen Sea shelf indicates that initial deglaciation was very early when compared to other regions of the West Antarctic shelf. For example, the APIS began to retreat from the north-western shelf of the Antarctic Peninsula at $\sim 15$ ka B.P. and from its south-western shelf at $\sim 12$ ka B.P. (Heroy and Anderson, 2005, 2007), while the WAIS began to retreat from the eastern Amundsen Sea shelf between $\sim 20$ and $16 \mathrm{ka}$ B.P. (Lowe and Anderson, 2002) and from the Ross Sea shelf between $\sim 21$ and 14 ka B.P. (Licht et al., 1996, 1998, 1999; Bindschadler, 1998; Conway et al., 1999; Domack et al., 1999; Licht and Andrews, 2002; Mosola and Anderson, 2006). However, the eastern Weddell Sea shelf may have started to become free of grounded ice at the same time as the southern Bellingshausen Sea shelf, while the Cosmonaut Sea shelf may have deglaciated as early as $\sim 30$ ka B.P. (Anderson et al., 2002, and references therein). Early initial ice-sheet retreat at $\sim 30 \mathrm{ka}$ B.P. is also reported for the Bunger Hills, East Antarctica (Gore et al., 2001).

It is important to note that Belgica Trough is larger than any other glacial trough along the Pacific margin of West Antarctica (cf. Shipp et al., 1999; Wellner et al., 2001, 2006; Lowe and Anderson, 2002; Heroy and Anderson, 2005; Ó Cofaigh et al., 2005a,b; Walker et al., 2007; Larter et al., 2009). The ice stream flowing through Belgica Trough also probably differed from other West Antarctic ice streams, because it drained an area $>200,000 \mathrm{~km}^{2}$ in the hinterland (see Fig. 9 in Ó Cofaigh et al., 2005b). Additionally, modern uplift rates and crustal uplift in the direct hinterland of Belgica Trough seem to be the highest in the whole of Antarctica and suggest significant glacial isostatic adjustment of this area
(Ivins and James, 2005; Riva et al., 2009). All these observations are consistent with a rather unique glacial history of the southern Bellingshausen Sea shelf and its hinterland and with a continuous, prolonged ice-sheet retreat as it is indicated by our chronology (Fig. 10). In any case, the timelines of ice-stream retreat in the study area (Fig. 10) strongly suggest that, similar to the Ross Sea shelf (Bindschadler, 1998; Conway et al., 1999), post-LGM deglaciation of both the WAIS and the APIS is still in progress.

Our ice-retreat chronology indicates that the deglaciation of the southern Bellingshausen Sea shelf may have contributed to global meltwater pulses at 17.1, 12.5 and 9.5 ka B.P. (Fairbanks, 1989; Clark et al., 2002, 2004), but was probably not responsible for any particular meltwater pulse (Fig. 10). The ice-stream retreat through Belgica Trough was apparently slower than the retreat of other palaeo-ice streams from the West Antarctic shelf (Licht et al., 1996, 1998, 1999; Bindschadler, 1998; Conway et al., 1999; Domack et al., 1999; Licht and Andrews, 2002; Lowe and Anderson, 2002; Heroy and Anderson, 2005, 2007; Mosola and Anderson, 2006; McKay et al., 2008). The slower retreat in our study area may result from the slightly seaward dipping middle-outer shelf profile in the southern Bellingshausen Sea (slope angle $\sim 0.08^{\circ}$, see Fig. 1 in Hillenbrand et al., 2005), which is unusual for the West Antarctic shelf, but may have delayed grounding-line retreat (Thomas and Bentley, 1978; Schoof, 2007).

Our reconstructed velocities for the ice-stream retreat from Belgica Trough range from 7 to $55 \mathrm{~m} / \mathrm{yr}$, which is very slow when compared to the grounding-line retreat velocity of $\sim 550 \mathrm{~m} / \mathrm{yr}$ observed for Pine Island Glacier (Amundsen Sea) between 1992 and 1996 (Rignot, 2002). However, grounding-zone wedges were 
observed in Belgica Trough by Ó Cofaigh et al. (2005b), which indicate that the ice-stream retreat was episodic (Dowdeswell et al., 2008b; Ó Cofaigh et al., 2008). Thus, it is conceivable that there may have been considerable variations in retreat rates between grounding-line positions. These variations may not be captured by our deglaciation chronology because it provides only mean velocities.

The lithology of the sediment cores from the southern Bellingshausen Sea shelf indicates that the ice stream retreating from Belgica Trough terminated in an ice shelf (Sections 4.1.1. and 4.1.2; Hillenbrand et al., 2005). A recent theoretical, glaciological study concluded that ice shelves fringing marine-based ice streams have a major buttressing effect (Goldberg et al., 2009). Therefore, the ice shelf of the ice stream flowing through Belgica Trough may also have delayed post-LGM grounding-line retreat and contributed to the observed slow and prolonged retreat pattern (Fig. 10).

\subsubsection{Open questions}

Our preferred deglaciation chronology raises some crucial questions. First, the ages for ice-stream retreat from sites GC366 GC368, GC372 and GC374 are significantly older than the ages further up-core (Fig. 2). Do even some of our preferred deglaciation ages lie in the lower limb of the "dog leg" as the age-depth profiles suggest for cores GC366, GC368 and GC374 (Fig. 7)? Not necessarily, we think, because during ice-sheet retreat a sub-ice shelf setting may be characterised by extremely low sedimentation rates or even no deposition (cf. Licht et al., 1998). When an ice shelf is large and/ or the rate of retreat is slow, a core site may remain for quite a long time in a zone roughly half way between the grounding line and the ice-shelf front, where depositional rates are extremely low due to the lack of particle supply (the "null zone" as defined by Domack et al., 1999). The same should apply for a core site that experiences a long period of permanent sea-ice cover.

Nevertheless, it remains a possibility that the AIO ${ }^{14} \mathrm{C}$ dates obtained from the middle lithological unit or the base of the upper unit in our cores may be unreliable ages for ice retreat. Although unlikely, we cannot entirely rule out that these dates provide the ages of reworked fossil organic material supplied from the grounding line of the retreating ice stream rather than the ages of fresh organic matter produced by planktonic organisms that lived subsequent to grounding-line retreat. In this scenario, ice-sheet advance and retreat across the shelf of the southern Bellingshausen Sea could only have occurred during a time window represented by a gap in the obtained $\mathrm{AIO}{ }^{14} \mathrm{C}$ dates. The only apparent gaps in our dates span the time intervals from 24.5 to 20.5 ka B.P. and 12.0 to 8.0 ka B.P., respectively (Fig. 7). Ice-sheet retreat during the former interval would indeed be consistent with the deglaciation history of other parts of the West Antarctic shelf (Section 4.2.2), while deglaciation during the latter interval seems to be too young. More sophisticated techniques of radiocarbon dating, such as compoundspecific AMS ${ }^{14} \mathrm{C}$ dating of the organic matter (e.g. Ingalls et al., 2004; Hatté et al., 2008; Ohkouchi and Eglinton, 2008; Rosenheim et al., 2008), are required to test these hypotheses.

Second, according to our preferred stratigraphy ice retreated from site GC357 at $6.3 \mathrm{ka}$ B.P. (Figs. 2, 10). This date is close to the age of 6.6 ka B.P., which we consider as deglaciation age for site GC359 near Beethoven Peninsula (Fig. 2). However, core GC358, which is located in close proximity of site GC359 (Fig. 1), recovered an expanded seasonal open-marine facies, whose basal age is 16.3 ka B.P. (Fig. 2). Is the older age from core GC358 more reliable than the age from site GC357? Again, it could be argued that the old age at site GC358 results from significant contamination, which may be supported by a slight kink in the age-depth profile (Fig. 7). However, even if the earlier deglaciation age is correct, we have to keep in mind that sites GC358 and GC359 were affected by ice flow towards NNW, but not into Belgica Trough (Fig. 1; Ó Cofaigh et al., 2005b). Therefore, ice-sheet retreat from sites GC358 and GC359 may have been decoupled from the ice-stream retreat along Belgica Trough (which controlled the deglaciation age of site GC357) and may have started significantly earlier.

Third, our reconstructed early start of deglaciation of the outer and middle shelf is not corroborated by the $\delta^{18} \mathrm{O}$ profiles from the corresponding core sites (Fig. 5a). Our $\delta^{18} \mathrm{O}$ data do not show the average global $\delta^{18} \mathrm{O}$ decrease of $\sim 1.0 \pm 0.2 \%$, which was caused by the melting of terrestrial ice-sheets and is typical for foraminiferal $\delta^{18} \mathrm{O}$ profiles spanning the last termination at 14 ka B.P. (e.g. Imbrie et al., 1984; Duplessy et al., 2002). Does the lack of the $\delta^{18} \mathrm{O}$ shift indicate that the sediments are younger than $14 \mathrm{ka}$ B.P.? Due to a lack of calcareous benthic foraminifera, we had to analyse $N$. pachyderma sin. tests. The data may be overprinted by local temperature and salinity changes in the surface waters. Hendry et al. (2009) showed that on the shelf west of the Antarctic Peninsula, which is significantly affected by the seasonal freezing and melting of sea ice, the $\delta^{18} \mathrm{O}$ values of recent planktonic foraminifera may vary up to $0.7 \%$ throughout the year. Using salinity data that were measured within the habitat of N. pachyderma sin. (i. e. within the upper $300 \mathrm{~m}$ of the water column) in our study area (Jenkins and Jacobs, 2008), we calculated hypothetical $\delta^{18} \mathrm{O}$ values for seawater on the southern Bellingshausen Sea shelf. We found that even at present the $\delta^{18} \mathrm{O}$ values may vary from $-0.8 \%$ to $+0.3 \%$ (using the equation of Kohfeld et al., 2000) and from $-0.9 \%$ to $+0.1 \%$ (using the equation of Duplessy et al., 1991), respectively. This local variability of seawater $\delta^{18} \mathrm{O}$ could indeed wipe out any global termination signal in the N. pachyderma sin. tests. However, the low amplitudes of the $\delta^{18} \mathrm{O}$ fluctuations in the cores from the southern Bellingshausen Sea (Fig. 5a) seem to contradict this explanation.

Fourth, a grounded ice stream, which extended north of the modern George VI Ice Shelf through Marguerite Trough to the shelf break of the Antarctic Peninsula, retreated from the outer to the inner shelf between $\sim 12.1$ and 8.4 ka B.P. (Ó Cofaigh et al., 2005a; Heroy and Anderson, 2007). Thereafter, the northern part of the George VI Ice Shelf collapsed (or at least its northern front retreated significantly south of its modern position) at $\sim 8.1 \mathrm{ka}$ B.P. (Bentley et al., 2005). The northern part of the ice shelf re-established (or its northern front re-advanced) after 7.3 ka B.P. Our post-LGM iceretreat reconstruction for the southern part of the George VI Ice Shelf indicates that grounded ice or an ice shelf cleared the inner shelf in Ronne Entrance not before $\sim 4.0$ ka B.P. (Fig. 10b). Are these different deglaciation histories for the northern and southern parts of the George VI Ice Shelf feasible? Probably, they are only compatible, if the deglaciation of the southern Bellingshausen Sea shelf was decoupled from the post-LGM ice-sheet retreat in other areas of the APIS and the WAIS (cf. Section 4.2.2).

\section{Conclusions}

- In sediment cores from the continental shelf and uppermost slope of the southern Bellingshausen Sea down-core changes in clay mineral assemblages allow the identification of the most reliable AIO ${ }^{14} \mathrm{C}$ ages for ice-sheet retreat from the core sites.

- The last advance of a grounded ice stream through Belgica Trough must have occurred after 36.0 ka B.P., and possibly after $32.7 \mathrm{ka}$ B.P. The outer trough deglaciated at $\sim 25.5 \mathrm{ka}$ B.P., the middle part of the trough at $\sim 19.8$ ka B.P., the inner shelf in Eltanin Bay at $\sim 12.3 \mathrm{ka}$ B.P., and the inner shelf in Ronne Entrance at $\sim 6.3 \mathrm{ka}$ B.P.

- The retreat of the WAIS and the APIS from the shelf of the southern Bellingshausen Sea started earlier than in other parts of the West Antarctic shelf, suggesting a unique ice-sheet 
history. In the study area, post-LGM deglaciation of both the WAIS and the APIS may still be in progress.

- The style of ice-stream retreat from Belgica Trough was episodic, slow and prolonged. The deglaciation of the southern Bellingshausen Sea shelf may have contributed to global meltwater pulses at 17.1, 12.5 and 9.5 ka B.P., but did not cause a particular meltwater pulse.

- Some problems regarding the chronology of ice-sheet retreat from the southern Bellingshausen Sea shelf are still unresolved and should be addressed by compound-specific $\mathrm{AIO}{ }^{14} \mathrm{C}$ dating in the future.

\section{Acknowledgements}

This work was supported by the NERC Antarctic Funding Initiative (project AFI 4/17) and the GRADES-QWAD and Palaeo-Ice Sheets projects at BAS. The authors thank A. Baesler, H. Blagbrough, B. Davies, S. Dorn, S. Elmer, J. Evans, R. Fröhlking, M. Hall, J. Howe, G. Kuhn, K. Linse, A. Mackensen, C. Manning, P. Morris, F. Niessen, C. Pudsey, R. Pugh, K. Rinne, A. Scharf, G. Schmiedl, M. Seebeck, T. Shimmield, J. Smith and J. Sothcott for their help, and the captains, officers, crew and support staff, who participated in cruises JR104 and ANT-XI/3. The authors are also grateful to S. Passchier and E. Domack, whose comments and suggestions improved the manuscript.

\section{Appendix. Supplementary data}

Supplementary data associated with this article can be found, in the on-line version, at doi: 10.1016/j.quascirev.2010.06.028.

\section{References}

Abelmann, A., Gersonde, R., Cortese, G., Kuhn, G., Smetacek, V., 2006. Extensive phytoplankton blooms in the Atlantic sector of the glacial Southern Ocean. Paleoceanography 21, PA1013. doi:10.1029/2005PA001199.

Alley, R.B., Clark, P.U., Huybrechts, P., Joughin, I., 2005. Ice-sheet and sea-level changes. Science 310, 456-460.

Anderson, J.B., 1999. Antarctic Marine Geology. Cambridge University Press, Cambridge, UK, $289 \mathrm{pp}$

Anderson, J.B., Kurtz, D.D., Domack, E.W., Balshaw, K.M., 1980. Glacial and glacialmarine sediments of the Antarctic continental shelf. Journal of Geology 27, 399-414.

Anderson, J.B., Shipp, S.S., Lowe, A.L., Wellner, J.S., Mosola, A.B., 2002. The Antarctic Ice Sheet during the Last Glacial Maximum and its subsequent retreat history: a review. Quaternary Science Reviews 21, 49-70.

Andrews, J.T., Domack, E.W., Cunningham, W.L., Leventer, A., Licht, K.J., Jull, A.J.T., DeMaster, D.J., Jennings, A.E., 1999. Problems and possible solutions concerning radiocarbon dating of surface marine sediments, Ross Sea, Antarctica. Quaternary Research 52, 206-216.

Bamber, J.L., Riva, R.E.M., Vermeersen, B.L.A., LeBrocq, A.M., 2009. Reassessment of the potential sea-level rise from a collapse of the West Antarctic Ice Sheet. Science 234, 901-903.

Bassett, S.E., Milne, G.A., Bentley, M.J., Huybrechts, P., 2007. Modeling Antarctic sealevel data to explore the possibility of a dominant Antarctic contribution to Meltwater Pulse 1A. Quaternary Science Reviews 26, 2113-2127.

Bentley, M.J., Hodgson, D.A., Sugden, D.E., Roberts, S.J., Smith, J.A., Leng, M.J., Bryant, C., 2005. Early Holocene retreat of the George VI Ice Shelf, Antarctic Peninsula. Geology 33, 173-176.

Bentley, M.J., Fogwill, C.J., Kubik, P.W., Sugden, D.E., 2006. Geomorphological evidence and cosmogenic ${ }^{10} \mathrm{Be} /{ }^{26} \mathrm{Al}$ exposure ages for the Last Glacial Maximum and deglaciation of the Antarctic Peninsula Ice Sheet. Geological Society of America Bulletin 118, 1149-1159.

Bentley, M.J., Hodgson, D.A., Smith, J.A., Ó Cofaigh, C., Domack, E.W., Larter, R.D., Roberts, S.J., Brachfeld, S., Leventer, A., Hjort, C., Hillenbrand, C.-D., Evans, J., 2009. Mechanisms of Holocene palaeoenvironmental change in the Antarctic Peninsula region. The Holocene 19, 51-66.

Berkman, P.A., Forman, S.L., 1996. Pre-bomb radiocarbon and the reservoir correction for calcareous marine species in the Southern Ocean. Geophysical Research Letters 23, 363-366.

Bindschadler, R., 1998. Future of the West Antarctic Ice Sheet. Science 282, 428-429.

Bingham, R.G., King, E.C., Larter, R.D., Pritchard, H.D., Smith, A.M., Vaughan, D.G., 2010. Ferrigno Ice Stream, West Antarctica: new boundary conditions for a catchment losing ice rapidly to dynamic thinning. Geophysical Research Abstracts 12, EGU2010-4657.

Brachfeld, S., Domack, E., Kissel, C., Laj, C Leventer A., Ishman, S., Gilbert, R., Camerlenghi, A., Eglinton, L.B., 2003. Holocene history of the Larsen-A Ice Shelf constrained by geomagnetic paleointensity dating. Geology 31, 749-752.

Clark, P.U., Mitrovica, J.X., Milne, G.A., Tamisiea, M.E., 2002. Sea-level finger printing as a direct test for the source of global Meltwater Pulse 1A. Science 295, $2438-2441$.

Clark, P.U., McCabe, A.M., Mix, A.C., Weaver, A.J., 2004. Rapid rise of sea level 19,000 years ago and its global implications. Science 304, 1141-1144.

Conway, H., Hall, B.L., Denton, G.H., Gades, A.M., Waddington, E.D., 1999. Past and future grounding-line retreat of the West Antarctic Ice Sheet. Science 286, 280-283.

Cunningham, A.P., Larter, R.D., Barker, P.F., Gohl, K., Nitsche, F.-O., 2002. Tectonic evolution of the Pacific margin of Antarctica: 2. Structure of late Cretaceous-early Tertiary plate boundaries in the Bellingshausen Sea from seismic reflection and gravity data. Journal of Geophysical Research 107 (B12), 2346. doi:10.1029/2002JB001897.

De Lange, G.J., 1992. Distribution of exchangeable, fixed organic and total nitrogen in interbedded turbiditic/pelagic sediments of the Madeira Abyssal Plain, eastern North Atlantic. Marine Geology 109, 95-114.

DeMaster, DJ., Ragueneau, O., Nittrouer, CA. 1996. Preservation efficiencies and accumulation rates for biogenic silica and organic $\mathrm{C}, \mathrm{N}$, and $\mathrm{P}$ in high-latitude sediments: the Ross Sea. Journal of Geophysical Research C101, 18501-18518.

Domack, E.W., 1992. Modern carbon-14 ages and reservoir corrections for the Antarctic Peninsula and Gerlache Strait area. Antarctic Journal of the U.S. 27, 63-64.

Domack, E., O’Brien, P., Harris, P., Taylor, F., Quilty, P.G., De Santis, L., Raker, B., 1998. Late Quaternary sediment facies in Prydz Bay, East Antarctica, and their relationship to glacial advance onto the continental shelf. Antarctic Science 10, 236-246.

Domack, E.W., Jacobson, E.A. Shipp, S.S., Anderson, J.B., 1999. Late Pleistocene-Holocene retreat of the West Antarctic Ice-Sheet system in the Ross Sea: Part 2-Sedimentologic and stratigraphic signature. Geological Society of America Bulletin 111, 1517-1536.

Domack, E.W., Leventer, A., Dunbar, R., Taylor, F., Brachfeld, S., Sjunneskog, C., ODP Leg 178 Scientific Party, 2001. Chronology of the Palmer Deep site, Antarctic Peninsula: a Holocene paleoenvironmental reference for the circum-Antarctic. The Holocene 11, 1-9.

Domack, E., Duran, D., Leventer, A., Ishman, S., Doane, S.S., McCallum, S., Amblas, D., Ring, Gilbert, R., Prentice, M., 2005. Stability of the Larsen B ice shelf on the Antarctic Peninsula during the Holocene epoch. Nature 436, 681-685.

Dowdeswell, J.A., Bamber, J.L., 2007. Keel depths of modern Antarctic icebergs and implications for sea-floor scouring in the geological record. Marine Geology 243, 120-131.

Dowdeswell, J.A., Evans, J., Ó Cofaigh, C., Anderson, J.B., 2006. Morphology and sedimentary processes on the continental slope off Pine Island Bay, Amundsen Sea, West Antarctica. Geological Society of America Bulletin 118, 606-619.

Dowdeswell, J.A., Ó Cofaigh, C., Noormets, R., Larter, R.D., Hillenbrand, C.-D., Benetti, S., Evans, J., Pudsey, C.J., 2008a. A major trough-mouth fan on the continental margin of the Bellingshausen Sea, West Antarctica: the Belgica Fan. Marine Geology 252, 129-140.

Dowdeswell, J.A., Ottesen, D., Evans, J., Ó Cofaigh, C., Anderson, J.B., 2008b. Submarine glacial landforms and rates of ice-stream collapse. Geology 36, 819-822.

Drewry, D.J., 1983. Antarctica: Glaciological and Geophysical Folio. Scott Polar Research Institute, Cambridge.

Duplessy, J.-C., Labeyrie, L.D., Juillet-Leclerc, A., Maitre, F., Duprat, J., Sarnthein, M., 1991. Surface salinity reconstruction of the North Atlantic Ocean during the last glacial maximum. Oceanologica Acta 14, 311-324.

Duplessy, J.-C., Labeyrie, D., Waelbroeck, C., 2002. Constraints on the ocean oxygen isotopic enrichment between the Last Glacial Maximum and the Holocene: paleoceanographic implications. Quaternary Science Reviews 21, 315-330.

Emslie, S.D., Coats, L., Licht, K., 2007. A 45,000 yr record of Adélie penguins and climate change in the Ross Sea, Antarctica. Geology 35, 61-64.

Evans, J., Pudsey, C.J., 2002. Sedimentation associated with Antarctic Peninsula ice shelves: implications for paleoenvironmental reconstructions of glacimarine sediments. Journal of the Geological Society 159, 233-237.

Evans, J., Pudsey, C.J., Ó Cofaigh, C., Morris, P.W., Domack, E.W., 2005. Late Quaternary glacial history, dynamics and sedimentation of the eastern margin of the Antarctic Peninsula Ice Sheet. Quaternary Science Reviews 24, 741-774.

Fairbanks, R.G., 1989. A 17 000-year glacio-eustatic sea level record: influence of glacial melting rates on the Younger Dryas event and deep ocean circulation. Nature 342, 637-642.

Ferrigno, J.G., Williams Jr., R.S., Rosanova, C.E., Lucchitta, B.K., Swithinbank, C., 1998. Analysis of coastal change in Marie Byrd Land and Ellsworth Land, West Antarctica, using Landsat imagery. Annals of Glaciology 27, 33-40.

Gersonde, R., Crosta, X., Abelmann, A., Armand, L., 2005. Sea-surface temperature and sea ice distribution of the Southern Ocean at the EPILOG Last Glacial Maximum - a circum-Antarctic view based on siliceous microfossil records. Quaternary Science Reviews 24, 869-896.

Glasby, G.P. (Ed.), 1990. Antarctic Sector of the Pacific. Elsevier Oceanography Series 51. Elsevier, Amsterdam, $396 \mathrm{pp}$

Goldberg, D., Holland, D.M., Schoof, C., 2009. Grounding line movement and ice shelf buttressing in marine ice sheets. Journal of Geophysical Research 114, F04026. doi:10.1029/2008JF001227. 
Gordon, J.E., Harkness, D.D., 1992. Magnitude and geographic variation of the radiocarbon content in Antarctic marine life: implications for reservoi corrections in radiocarbon dating. Quaternary Science Reviews 11, 696-708.

Gore, D.B., Rhodes, E.J., Augustinus, P.C., Leishman, M.R., Colhoun, E.A., Rees-Jones, J. 2001. Bunger Hills, East Antarctica: ice free at the Last Glacial Maximum. Geology 29, 1103-1106.

Harden, S.L., DeMaster, D.J., Nittrouer, C.A., 1992. Developing sediment geochronologies for high-latitude continental shelf deposits: a radiochemical approach. Marine Geology 103, 69-97.

Hatté, C., Hodgins, G., Jull, A.J.T., Bishop, B., Tesson, B., 2008. Marine chronology based on ${ }^{14} \mathrm{C}$ dating on diatoms proteins. Marine Chemistry 109, 143-151.

Hemer, M.A., Post, A.L., O'Brien, P.E., Craven, M., Truswell, E.M., Roberts, D., Harris, P. T., 2007. Sedimentological signatures of the sub-Amery Ice Shelf circulation. Antarctic Science 19, 497-506.

Hendry, K.R., Rickaby, R.E.M., Meredith, M.P., Elderfield, H., 2009. Controls on stable isotope and trace metal uptake in Neogloboquadrina pachyderma (sinistral) from an Antarctic sea-ice environment. Earth and Planetary Science Letters 278, 67-77.

Heroy, D.C., Anderson, J.B., 2005. Ice-sheet extent of the Antarctica Peninsula region during the Last Glacial Maximum (LGM) - insights from glacial geomorphology. Geological Society of America Bulletin 117, 1497-1512.

Heroy, D.C., Anderson, J.B., 2007. Radiocarbon constraints on Antarctic Peninsula Ice Sheet retreat following the Last Glacial Maximum (LGM). Quaternary Science Reviews 26, 3286-3297.

Hillenbrand, C.-D., Grobe, H., Diekmann, B., Kuhn, G., Fütterer, D., 2003. Distribution of clay minerals and proxies for productivity in surface sediments of the Bellingshausen and Amundsen seas (West Antarctica) - relation to modern environmental conditions. Marine Geology 193, 253-271.

Hillenbrand, C.-D., Baesler, A., Grobe, H., 2005. The sedimentary record of the last glaciation in the western Bellingshausen Sea (West Antarctica): implications for the interpretation of diamictons in a polar-marine setting. Marine Geology 216 191-204.

Hillenbrand, C.-D., Ehrmann, W., Larter, R.D., Benetti, S., Dowdeswell, J.A., Ó Cofaigh, C., Graham, A.G.C., Grobe, H., 2009. Clay mineral provenance of sediments in the southern Bellingshausen Sea reveals drainage changes of the West Antarctic Ice Sheet during the Late Quaternary. Marine Geology 265, 1-18.

Hillenbrand, C.-D., Smith, J.A., Kuhn, G., Esper, O., Gersonde, R., Larter, R.D., Maher, B., Moreton, S.G., Shimmield, T.M., Korte, M., 2010. Age assignment of a diatomaceous ooze deposited in the western Amundsen Sea embayment after the Last Glacial Maximum. Journal of Quaternary Science 25, 280-295.

Imbrie, J., Hays, J.D., Martinson, D.G., McIntyre, A., Mix, A.C., Morley, J.J., Pisias, N.G. Prell, W.L., Shackleton, N.J., 1984. The orbital theory of Pleistocene climate: support from a revised chronology, of the marine $\delta^{18} \mathrm{O}$ record. In: Berger, A. Imbrie, J., Hays, J., Kukla, G., Saltzmann, B. (Eds.), Milankovitch and Climate, Part 1. Springer, New York, pp. 269-305.

Ingalls, A.E., Anderson, R.F., Pearson, A., 2004. Radiocarbon dating of diatom-bound organic compounds. Marine Chemistry 92, 91-105.

Ivins, E.R., James, T.S., 2005. Antarctic glacial isostatic adjustment: a new assessment. Antarctic Science 17, 541-553.

Jacobs, S.S., Hellmer, H.H., Jenkins, A., 1996. Antarctic ice sheet melting in the Southeast Pacific. Geophysical Research Letters 23, 957-960. doi:10.1029/ 96GL00723.

Jenkins, A., Jacobs, S., 2008. Circulation and melting beneath George VI Ice Shelf, Antarctica. Journal of Geophysical Research 113, C04013. doi:10.1029/ 2007JC004449.

Johnson, J.S., Bentley, M.J., Gohl, K., 2008. First exposure ages from the Amundsen Sea Embayment, West Antarctica: the Late Quaternary context for recen thinning of Pine Island, Smith, and Pope Glaciers. Geology 36, 223-226.

Kohfeld, K.E., Anderson, R.F., Lynch-Stieglitz, J., 2000. Carbon isotopic disequilibrium in polar planktonic foraminifera and its impact on modern and Last Glacial Maximum reconstructions. Paleoceanography 16, 53-64.

Kurtz, D.D., Anderson, J.B., 1979. Recognition and sedimentologic description of recent debris flow deposits from the Ross and Weddell seas, Antarctica. Journa of Sedimentary Petrology 49, 1159-1170.

Lamb, A.L., Wilson, G.P., Leng, M.J., 2006. A review of coastal palaeoclimate and relative sea-level reconstructions using $\delta^{13} \mathrm{C}$ and $\mathrm{C} / \mathrm{N}$ ratios in organic material. Earth-Science Reviews 75, 29-57.

Larter, R.D., Graham, A.G.C., Gohl, K., Kuhn, G., Hillenbrand, C.-D., Smith, J.A Deen, T.J. Livermore, R.A., Schenke, H.-W., 2009. Subglacial bedforms revea complex basal regime in a zone of paleo-ice stream convergence, Amundsen Sea embayment, West Antarctica. Geology 37, 411-414.

Licht, K.J., 2004. The Ross Sea's contribution to eustatic sea-level during Meltwater Pulse 1A. Sedimentary Geology 165, 343-353.

Licht, K.J., Andrews, J.T., 2002. The ${ }^{14} \mathrm{C}$ record of Late Pleistocene ice advance and retreat in the central Ross Sea, Antarctica. Arctic, Antarctic and Alpine Research 34, 324-333.

Licht, K.J., Jennings, A.E., Andrews, J.T., Williams, K.M., 1996. Chronology of late Wisconsin ice retreat from the western Ross Sea, Antarctica. Geology 24, 223-226.

Licht, K.J., Cunningham, W.L., Andrews, J.T., Domack, E.W., Jennings, A.E., 1998. Establishing chronologies from acid-insoluble organic ${ }^{14} \mathrm{C}$ dates on Antarctic (Ross Sea) and Arctic (North Atlantic) marine sediments. Polar Research 17, 203-216.

Licht, K.J., Dunbar, N.W., Andrews, J.T., Jennings, A.E., 1999. Distinguishing subglacial till and glacial marine diamictons in the western Ross Sea, Antarctica: implications for a Last Glacial Maximum grounding line. Geological Society of America Bulletin 111, 91-103.
Lowe, A.L., Anderson, J.B., 2002. Late Quaternary retreat of the West Antarctic Ice Sheet in Pine Island Bay, Antarctica. Quaternary Science Reviews 21, 1879-1897.

McKay, R.M., Dunbar, G.B., Naish, T.R., Barrett, P.J., Carter, L., Harper, M., 2008. Retreat history of the West Antarctic Ice (Sheet) Shelf in western Ross Sea since the Last Glacial Maximum from deep-basin sediment cores. Palaeogeography, Palaeoclimatology, Palaeoecology 260, 168-183.

McMinn, A., Heijnis, H., Harle, K., McOrist, G., 2001. Late-Holocene climatic change recorded in sediment cores from Ellis Fjord, eastern Antarctica. Holocene 11, 291-300.

Meyers, P.A., 1997. Organic geochemical proxies of paleoceanographic, paleolimnologic and paleoclimatic processes. Organic Geochemistry 27, 213-250.

Miller, H., Grobe, H. (Eds.), 1996. Die Expedition Antarktis-XI/3 mit FS “Polarstern" 1994. Reports on Polar Research 188. Alfred Wegener Institute for Polar and Marine Research, Bremerhaven, 115 pp.

Mosola, A.B., Anderson, J.B., 2006. Expansion and rapid retreat of the West Antarctic ce Sheet in eastern Ross Sea: possible consequence of over extended ice streams? Quaternary Science Reviews 25, 2177-2196.

Nishimura, A., Tanahashi, M., Tokuhashi, S., Oda, H., Nakasone, T., 1999. Marine sediment cores from the continental shelf around Anvers Island, Antarctic Peninsula region. Polar Geoscience 12, 215-226.

Nitsche, F.O., Gohl, K., Vanneste, K., Miller, H., 1997. Seismic expression of glacially deposited sequences in the Bellingshausen and Amundsen seas, West Antarctica. In: Barker, P.F., Cooper, A.K. (Eds.), Geology and Seismic Stratigraphy of the Antarctic Margin 2. Antarctic Research Series 71. American Geophysical Union, Washington D.C., pp. 95-108.

Nitsche, F.O., Cunningham, A.P., Larter, R.D., Gohl, K., 2000. Geometry and development of glacial continental margin depositional systems in the Bellingshausen Sea. Marine Geology 162, 277-302.

Noormets, R., Dowdeswell, J.A., Larter, R.D., Ó Cofaigh, C., Evans, J., 2009 Morphology of the upper continental slope in the Bellingshausen and Amundsen Seas - implications for sedimentary processes at the shelf edge of West Antarctica. Marine Geology 258, 100-114.

Ó Cofaigh, C., Dowdeswell, J.A., Allen, C.S., Hiemstra, J., Pudsey, C.J., Evans, J., Evans, D.J.A., 2005a. Flow dynamics and till genesis associated with a marinebased Antarctic palaeo-ice stream. Quaternary Science Reviews 24, 709-740.

Ó Cofaigh, C., Larter, R.D., Dowdeswell, J.A., Hillenbrand, C.-D., Pudsey, C.J., Evans, J., Morris, P., 2005b. Flow of the West Antarctic Ice Sheet on the continental margin of the Bellingshausen Sea at the Last Glacial Maximum. Journal of Geophysical Research 110, B11103. doi:10.1029/2005JB003619.

Ó Cofaigh, C., Evans, J., Dowdeswell, J.A., Larter, R.D., 2007. Till characteristics, genesis and transport beneath Antarctic paleo-ice streams. Journal of Geophysical Research 112, F03006. doi:10.1029/2006JF000606.

Ó Cofaigh, C., Dowdeswell, J.A., Evans, J., Larter, R.D., 2008. Geological constraints on Antarctic palaeo-ice-stream retreat. Earth Surface Processes and Landforms 33 , 513-525.

Ohkouchi, N., Eglinton, T.I., 2006. Radiocarbon constraint on relict organic carbon contributions to Ross Sea sediments. Geochemistry, Geophysics, Geosystems 7 , Q04012. doi:10.1029/2005GC001097.

Ohkouchi, N., Eglinton, T.I., 2008. Compound-specific radiocarbon dating of Ross Sea sediments: a prospect for constructing chronologies in high-latitude oceanic sediments. Quaternary Geochronology 3, 235-243.

Oppenheimer, M., 1998. Global warming and the stability of the West Antarctic Ice Sheet. Nature 393, 325-332.

Orsi, A.H., Whitworth III, T., Nowlin Jr., W.D., 1995. On the meridional extent and fronts of the Antarctic Circumpolar Current. Deep-Sea Research I 42 641-673.

Peltier, W.R., 2005. On the hemispheric origins of Meltwater Pulse 1A. Quaternary Science Reviews 24, 1655-1671.

Presti, M., De Santis, L., Busetti, M., Harris, P.T., 2003. Late Pleistocene and Holocene sedimentation on the George V Continental Shelf, East Antarctica. Deep-Sea Research II 50, 1441-1451.

Pritchard, H.D., Vaughan, D.G., 2007. Widespread acceleration of tidewater glaciers on the Antarctic Peninsula. Journal of Geophysical Research 112, F03S29. doi:10.1029/2006JF000597.

Pritchard, H.D., Arthern, R.J., Vaughan, D.G., Edwards, L.A., 2009. Extensive dynamic thinning on the margins of the Greenland and Antarctic ice sheets. Nature 461 971-975.

Pudsey, C.J., Evans, J., 2001. First survey of Antarctic sub-ice shelf sediments reveals mid-Holocene ice shelf retreat. Geology 29, 787-790.

Pudsey, C.J., Barker, P.F., Larter, R.D., 1994. Ice sheets retreat from the Antarctic Peninsula shelf. Continental Shelf Research 14, 1647-1675

Pudsey, C.J., Murray, J.W., Appleby, P., Evans, J., 2006. Ice shelf history from petrographic and foraminiferal evidence, Northeast Antarctic Peninsula. Quaternary Science Reviews 25, 2357-2379.

Rignot, E., 2002. Ice-shelf changes in Pine Island Bay, Antarctica, 1947-2000. Journal of Glaciology 48, 247-256.

Rignot, E., Casassa, G., Goginen, P., Krabill, W., Rivera, A., Thomas, R., 2004. Accelerated ice discharge from the Antarctic Peninsula following the collapse of Larsen B ice shelf. Geophysical Research Letters 31, L18401. doi:10.1029/ 2004 GL020697.

Rignot, E., Bamber, J.L., van den Broeke, M.R., Davis, C., Li, Y., van de Berg, W.J., van Meijgaard, E., 2008. Recent Antarctic ice mass loss from radar interferometry and regional climate modelling. Nature Geoscience 1, 106-110.

Riva, R.E.M., Gunter, B.C., Urban, T.J., Vermeersen, B.L.A., Lindenbergh, R.C., Helsen, M.M., Bamber, J.L., van de Wal, R.S.W., van den Broeke, M.R., Schutz, B.E. 
2009. Glacial isostatic adjustment over Antarctica from combined ICESat and GRACE satellite data. Earth and Planetary Science Letters 288, 516-523.

Rosenheim, B.E., Day, M.B., Domack, E., Schrum, H., Benthien, A., Hays, J.M., 2008. Antarctic sediment chronology by programmed-temperature pyrolysis: methodology and data treatment. Geochemistry, Geophysics, Geosystems 9, Q04005. doi:10.1029/2007GC001816.

Roy, S., 1981. Manganese Deposits. Academic Press, London, 458 pp.

Scambos, T.A., Bohlander, J., Shuman, C., Skvarca, P., 2004. Glacier acceleration and thinning after ice shelf collapse in the Larsen B embayment, Antarctica. Geophysical Research Letters 31, L18402. doi:10.1029/2004GL020670.

Scheuer, C., Gohl, K., Larter, R.D., Rebesco, M., Udintsev, G., 2006. Variability in Cenozoic sedimentation along the continental rise of the Bellingshausen Sea, West Antarctica. Marine Geology 227, 279-298.

Schoof, C., 2007. Marine ice-sheet dynamics. Part 1 . The case of rapid sliding. Journal of Fluid Mechanics 573, 27-55.

Shepherd, A., Wingham, D., 2007. Recent sea-level contributions of the Antarctic and Greenland ice sheets. Science 315, 1529-1532.

Shipp, S.S., Anderson, J.B., Domack, E.W., 1999. Late Pleistocene-Holocene retreat of the West Antarctic Ice-Sheet system in the Ross Sea: Part 1-Geophysical Results. Geological Society of America Bulletin 111, 1486-1516.

Smith, J.A., Hodgson, D.A., Bentley, M.J., Verleyen, E., Leng, M.J., Roberts, S.J., 2006. Limnology of two Antarctic epishelf lakes and their potential to record periods of ice shelf loss. Journal of Paleolimnology 35, 373-394.

Smith, J.A., Hillenbrand, C.-D., Larter, R.D., Graham, A.G.C., Kuhn, G., 2009. The sediment infill of subglacial meltwater channels on the West Antarctic continental shelf. Quaternary Research 71, 190-200.

Stone, J.O., Balco, G.A., Sugden, D.E., Caffee, M.C., Sass, L.C., Cowdery, S.G., Siddoway, C., 2003. Holocene deglaciation of Marie Byrd Land, West Antarctica. Science 299, 99-102.

Thoma, M., Jenkins, A., Holland, D., Jacobs, S., 2008. Modelling circumpolar deep water intrusions on the Amundsen Sea continental shelf, Antarctica. Geophysical Research Letters 35, L18602. doi:10.1029/2008GL034939.

Thomas, R.H., Bentley, C.R., 1978. A model for Holocene retreat of the West Antarctic Ice Sheet. Quaternary Research 10, 150-170.

Thomas, R., Rignot, E., Casassa, G., Kanagaratnam, P., Acuna, C., Akins, T., Brecher, H., Frederick, E., Gogineni, P., Krabill, W., Manizade, S., Ramamoorthy, H., Rivera, A.,
Russell, R., Sonntag, J., Swift, R., Yungel, J., Zwally, J., 2004. Accelerated sea-level rise from West Antarctica. Science 306, 255-258.

Vaughan, D.G., 2008. West Antarctic Ice Sheet collapse - the fall and rise of a paradigm. Climatic Change 91, 65-79.

Vaughan, D.G., Arthern, R., 2007. Why is it hard to predict the future of ice sheets? Science 315, 1503-1504.

Walker, D.P., Brandon, M.A., Jenkins, A., Allen, J.T., Dowdeswell, J.A., Evans, J., 2007. Oceanic heat transport onto the Amundsen Sea shelf through a submarine glacial trough. Geophysical Research Letters 34, L02602. doi:10.1029/ 2006 GL028154.

Wellner, J.S., Lowe, A.L., Shipp, S.S., Anderson, J.B., 2001. Distribution of glacial geomorphic features on the Antarctic continental shelf and correlation with substrate: implications for ice behavior. Journal of Glaciology 47, 397-411.

Wellner, J.S., Heroy, D.C., Anderson, J.B., 2006. The death mask of the Antarctic Ice Sheet: comparison of glacial geomorphic features across the continental shelf. Geomorphology 75, 157-171.

Whitworth III, T., Orsi, A.H. Kim, S.-J., Nowlin Jr., W.D., Locarnini, R.A. 1998, Water masses and mixing near the Antarctic slope front. In: Jacobs, S.S., Weiss, R. (Eds.), Ocean, Ice, and Atmosphere: Interactions at the Antarctic Continental Margin. Antarctic Research Series 75. American Geophysical Union, Washington D.C., pp. 1-27.

Wingham, D.J., Wallis, D.W., Shepherd, A., 2009. Spatial and temporal evolution of Pine Island Glacier thinning, 1995-2006. Geophysical Research Letters 36, L17501. doi:10.1029/2009GL039126.

Wright, R., Anderson, J.B., 1982. The importance of sediment gravity flow to sediment transport and sorting in a glacial marine environment: eastern Weddell Sea. Geological Society of America Bulletin 93, 951-963.

Yoon, H.I., Park, B.-K., Kim, Y., Kim, D., 2000. Glaciomarine sedimentation and its paleoceanographic implications along the fjord margins in the South Shetland Islands, Antarctica during the last 6000 years. Palaeogeography, Palaeoclimatology, Palaeoecology 157, 189-211.

Yoon, H.I., Yoo, K.-C., Bak, Y.-S., Lim, H.S., Kim, Y., Lee, J.I., 2010. Late Holocene cyclic glaciomarine sedimentation in a subpolar fjord of the South Shetland Islands, Antarctica, and its paleoceanographic significance: sedimentological, geochemical, and paleontological evidence. Geological Society of America Bulletin 122, 1298-1307. 